\title{
New prehistoric avifaunas from the Gambier Group, French Polynesia
}

\author{
Stanislas Rigal, Patrick V. Kirch, and Trevor H. Worthy
}

\begin{abstract}
This paper analyses 647 bird bones identifiable at least to family-level collected from archaeological sites in 2005, 2012 and 2014 by P. Kirch, in the Gambier Group, French Polynesia. The bones derive from Onemea Site (TAR-6) on Taravai Island, Nenega-Iti Rock Shelter (AGA-3) on Agakauitai Island and Kitchen Cave (KAM-1) on Kamaka Island. Eighteen bird species, four newly recorded in this archipelago, are represented among the bones from archaeological layers dating from human arrival in the tenth century to the late pre-European contact period in the early nineteeth century. They reveal that the original avifauna from the Gambier Group minimally included 37 species. These include six now extinct taxa, a species of Pseudobulweria petrel, two columbids (Bountyphaps obsoleta, Ducula tihonireasini n.sp. described herein) and three other land birds that were recorded historically. Minimally, a further six species have been extirpated from the Gambier Group. These archaeological avifaunas are strongly dominated by seabirds ( $89.4 \%$ Minimum Number Individuals) but differences in species representation and dominance suggest the composition of breeding seabird faunas differed between islands. Columbidae were the dominant land birds $(58.9 \%$ $\mathrm{MNI}$ ), although no species of this family currently exist on this archipelago.
\end{abstract}

Stanislas Rigal. Institut des Sciences de l'Evolution de Montpellier, Bâtiment 22, Université de Montpellier Place Eugène Bataillon, Cc 0665, 34095 Montpellier cedex 05, France. stanislas.rigal@ens-lyon.fr; formerly College of Science and Engineering, Flinders University, GPO 2100, Adelaide 5001, SA, Australia.

Patrick V. Kirch. University of California, Berkeley, CA 94720. kirch@berkeley.edu

Trevor H. Worthy. College of Science and Engineering, Flinders University, GPO 2100, Adelaide 5001, SA, Australia. trevor.worthy@flinders.edu.au

Keywords: Mangareva; Pacific; archaeology; prehistoric birds; procellariiforms; columbids; new species

Submission: 18 May 2018 Acceptance: 16 November 2018

http://zoobank.org/2AB2225A-49DC-437F-B01D-CBFBB489C97C

Rigal, Stanislas, Kirch, Patrick V., and Worthy, Trevor H. 2018. New prehistoric avifaunas from the Gambier Group, French Polynesia. Palaeontologia Electronica 21.3.4A 1-35. https://doi.org/10.26879/892

palaeo-electronica.org/content/2018/2360-gambier-group-fossil-avifaunas

Copyright: December 2018 Paleontological Society.

This is an open access article distributed under the terms of Attribution-NonCommercial-ShareAlike 4.0 International (CC BY-NC-SA 4.0), which permits users to copy and redistribute the material in any medium or format, provided it is not used for commercial purposes and the original author and source are credited, with indications if any changes are made.

creativecommons.org/licenses/by-nc-sa/4.0/ 


\section{INTRODUCTION}

Extinctions, especially of birds, have often been the unintended consequence of human arrival on islands and the subsequent environmental changes resulting from human activities such as hunting, forest clearance, and habitat disturbance (Steadman, 2006; Kirch, 2007; Hume and Walters, 2012; Walther and Hume, 2016). Historical occurrence data has often documented many of these extinctions (Greenway, 1958; Fuller, 1987), but for many oceanic islands such historical records are lacking, so study of osseous remains is the only way to assess former diversity. However, due to the scarcity of suitable fossil deposits, the study of the archaeological record often provides the primary insight into the pre-human avifaunas. This is especially true for the Polynesian islands of the Pacific where the uneven geographic coverage of Pacific-wide archaeological investigations prevents biogeographers from fully appreciating human influences on the distribution of species, especially for birds (Steadman, 1997, 2006), and therefore restricts our understanding of the evolution of the fauna.

The Gambier Group lies in the southeast corner of French Polynesia, $180 \mathrm{~km}$ southeast of the Acteon Group in the Tuamotu Archipelago and 540 $\mathrm{km}$ northwest of Henderson Island, on the Tropic of Capricorn about midway between Australia and South America, see maps in Steadman (2006) and Thibault and Cibois (2017) showing the geographical context of the group within eastern Polynesia. Here we use the term Gambier Group for the entire set of 14 islands and islets that are encompassed within a barrier reef and lagoon to form a near atoll (Figure 1). The old and high (441 m) island of Mangareva $\left(14 \mathrm{~km}^{2}\right)$ and the 13 smaller associated islands are volcanic in origin. The Tuamotu-Gambier Archipelago owes its existence to the Pitcairn volcanic hotspot, which resulted in volcanic activity between 25 m.y.a. and 500 k.y.a. (Bonvallot et al., 1993; Hekinian, 2003). As the Pacific Plate advanced to the northwest across this hotspot, the volcanic islands of the Gambier Group were the penultimate group to be formed, between 6.0 and 4.8 m.y.a. (Bonvallot et al., 1993), with Pitcairn Island the most recent land to emerge from this volcanic activity. After Mangareva, Taravai $(256 \mathrm{~m}$, $\left.5.3 \mathrm{~km}^{2}\right)$, Akamaru $\left(2 \mathrm{~km}^{2}\right)$, Aukena $\left(1.5 \mathrm{~km}^{2}\right)$, Agakauitai $\left(0.7 \mathrm{~km}^{2}\right)$ and Kamaka $\left(0.5 \mathrm{~km}^{2}\right)$, are the five next largest islands in the Gambier Group. All of these islands including some islets (motu) are separated by relatively shallow water, but would have formed continuous land during most of the Pleistocene.

Archaeological research has revealed that the human pre-European colonization of the Polynesian region occurred in two distinct phases separated by approximately 1800 years (Anderson, 2001, 2003; Kirch et al., 2010; Kirch, 2017). The first phase occurred when people of the Lapita culture expanded eastwards from the Fijian archipelago to colonize the Samoa-Tonga area between 900-800 BC (Burley et al., 2012; Kirch, 2017:88, table 4.2). The second phase involved the expansion of Polynesians out of the Samoa-Tonga homeland into the central eastern Pacific beginning around AD 950, leading to the colonisation of the Society Islands, the Marquesas, Mangareva, the Pitcairn-Henderson group and Easter Island by approximately AD 1100 (Anderson and Sinoto, 2002; Conte and Anderson, 2003; Kirch, 2017:198200, table 7.2). The more remote Hawaiian archipelago was settled between AD 940-1130 (Athens et al., 2014), while New Zealand was not reached until AD 1140-1340 (Wilmshurst et al., 2008). Given these fairly recent dates for human arrival in the islands of eastern and marginal Polynesia, the impacts of humans on the avifaunas of the eastern Pacific are in all cases quite recent.

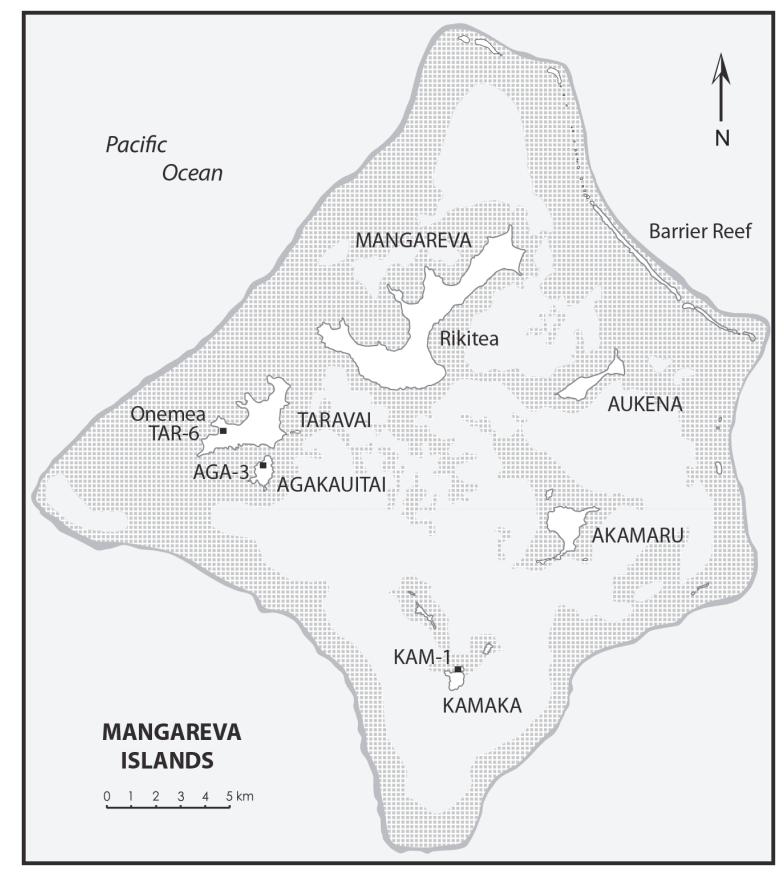

FIGURE 1. Map showing the various Mangareva Islands that comprise the Gambier Group in the eastern Pacific and locating the archaeological sites for which faunas are presented here. 
With regard to the fossil avifauna of the Tuamotu Archipelago and Gambier Group, Steadman (2006: 235) wrote "The lack of bird bones from this region is a void in the avian prehistory of Polynesia that rivals that of Upolu and Savai'i, the two largest islands in Samoa." The first insight into the avian prehistory of the Gambier Group derived from Roger Green's pioneering archaeological research in 1959, when he excavated five sites on Aukena, Kamaka and Mangareva dating to the eleventh to seventeeth centuries AD (Weisler, 1996; Green and Weisler, 2000, 2002, 2004; Steadman and Justice, 1998; Steadman, 2006: 236; Conte and Kirch, 2004, 2008). Green's excavations produced 215 identifiable bird bones, although only four were of native land birds (Steadman and Justice, 1998; Steadman, 2006). A new archaeological campaign launched by P. Kirch and E. Conte in 2001 and 2003 resulted in the discovery of abundant bird bones, especially in the Onemea or TAR- 6 site on Taravai Island (166 identified in test pit 2 at TAR-6; Worthy and Tennyson, 2004), foreshadowing the acquisition of a significant sample informing on the former Gambier avifaunas. The rich avifauna and associated early radiocarbon dates suggested that the Onemea site was likely to have been a pioneering settlement (Conte and Kirch, 2004; Conte et al., 2004; Kirch and Conte, 2009). Further investigations at TAR- 6 in 2005 greatly expanded the sample of bird bones, and taphonomic analyses of about half of the 1185 recovered bird bones or fragments showed that they derived from birds that humans had consumed (Kirch et al., 2010). Analyses of other faunal remains indicate that the earliest colonisers introduced the Pacific rat (Rattus exulans) and probably pig to Taravai (Swift et al., 2016). Additional field campaigns by Kirch in 2012 and 2014 expanded the initial test excavation in site AGA-3 on Agakauitai Island, and re-excavated the Kitchen Cave (KAM-1) site on Kamaka Island first dug by Green; avifaunal remains were recovered from both of these sites. Here we report on the total available avifaunas from the TAR-6, AGA3 and KAM-1 sites, and present data on 647 bones identifiable to family-level or lower taxon levels, in total representing minimally 192 individuals.

\section{MATERIALS AND METHODS}

\section{Excavated Sites}

The TAR- 6 site on Taravai Island is a small calcareous dune at the head of Onemea Bay, on the island's southwest coast. Two test pits were excavated in 2003, revealing a rich concentration of bird bones at the cultural/pre-cultural stratigraphic interface (Conte and Kirch, 2004). This led to expanded excavations in 2005 , with an additional 10 units being dug, resulting in a total excavated area for the TAR- 6 site of $12 \mathrm{~m}^{2}$ (Kirch et al., 2010). The greatest concentration of bird bones, however, came from the initial test pit (TP) 2 , and from three adjacent units (TP-5, -6 , and -11) that formed a 1 by $3 \mathrm{~m}$ trench at the top of the dune, situated close to TP-2. In these four units, the stratigraphy consisted of a thin, organically enriched loam (Layer I) overlying a reddish-gray, charcoalenriched cultural deposit (Layer II) about $60 \mathrm{~cm}$ thick, which in turn overlies a reddish-yellow aeolian sand (Layer III) generally lacking charcoal but containing a high frequency of bird bones. Although not a midden deposit, the upper part of Layer III was clearly deposited after the arrival of Polynesians on the island, as this deposit contains the bones of human-transported rats (Rattus exulans) and landsnails (Allopeas gracile) along with a few basalt flakes and pieces of worked pearl shell. Eleven radiocarbon dates were obtained from the TAR- 6 site, and bracket initial human activity at the site between approximately AD 900-1100. The main cultural deposit (Layer II) accumulated between AD 1200-1400 (Kirch et al., 2010, table 1). This deposit also contains bird bones, although the density is considerably less than that in Layer III.

The Nenega-iti rockshelter (site AGA-3) lies at the base of the steep volcanic ridge on the northwestern side of Agakauitai Island, about $100 \mathrm{~m}$ from the present shoreline. A mere overhang with a surface area of about $35 \mathrm{~m}^{2}$ inside the dripline, the shelter nonetheless has well-stratified deposits with evidence of substantial occupation. A single test pit excavated in 2003 (Conte and Kirch, 2004:87-90) did not fully penetrate to the deepest occupation deposits. In 2012, an excavation of 9 $\mathrm{m}^{2}$ exposed a significantly expanded sample (Kirch et al., 2015). In particular, the D9/E9/F9 trench exposed a $40-50 \mathrm{~cm}$ thick cultural deposit (Layer IV) with considerable numbers of bird bones near the base and at the interface with the underlying pre-cultural deposit (Layer V). Seven radiocarbon dates (Kirch et al., 2015, table 1, figure 7) indicate initial occupation beginning around AD 1300, with use of the shelter continuing up until the early postEuropean contact period.

The large Kitchen Cave rockshelter (KAM-1) on Kamaka Island, first excavated by Green in 1959, was re-examined by Kirch and his team in 2012, revealing well-stratified deposits in an area 
adjacent to Green's original excavation. In 2014, this test pit was expanded with an additional $4 \mathrm{~m}^{2}$, for a total of $5 \mathrm{~m}^{2}$. The 2012-2014 excavations have yet to be published in full, but a series of 13 radiocarbon dates indicates initial occupation beginning around AD 1300 and more-or-less continual use of the rockshelter (probably intermittently) until European contact. The occupation sequence at KAM-1 thus closely parallels that at AGA-3.

\section{Methods}

We examined bird bones from three sites as follows: 1185 bones from Onemea (Site 190-12TAR-6) on Taravai Island, 386 bones from NenegaIti Rock Shelter (Site 190-02-AGA-3) on Agakauitai Island and 280 bones from Kitchen Cave (Site 19004-KAM-1) on Kamaka Island, collected by P. Kirch et al. in 2005, 2012 and 2014 respectively. The bones previously reported from the Onemea and Nenega-Iti sites (Worthy and Tennyson, 2004) were re-examined and integrated in the analysis. In total, the collection comprised 647 bird bones identified to family or lower taxon levels and 1362 unidentifiable bird bone fragments. The collections are mainly curated at the Service de la Culture et du Patrimoine, overseen by the Ministry of Culture, Government of French Polynesia, Tahiti, but a small series was deposited in the Museum of New Zealand Te Papa Tongarewa, Wellington, New Zealand, to facilitate taxonomic comparisons.

Specimens were examined under magnification with a binocular microscope for anatomical features and to compare to reference specimens. Comparisons were made with modern skeletons where possible or to the material reported by Worthy and Tennyson (2004), which was identified with reference to the extensive seabird skeletal holdings in the Museum of New Zealand Te Papa Tongarewa (Wellington, New Zealand). In particular, the bones previously identified as Pseudobulweria species (Worthy and Tennyson 2004) were our primary reference material for this taxon.

\section{Abbreviations}

Anatomical. ant, anterior; art, articular part of mandible; d, distal; juv, juvenile; $p$, proximal; pt, part; s, shaft; L, left; R, right; cmc, carpometacarpus; cor, coracoid; cran, cranial; dent, dentary; fem, femur; fur, furcula; hum; humerus; mand, mandible; phal, phalanx; pmx, premaxilla; quad, quadrate; rad, radius; scap, scapula; stern, sternum; tmt, tarsometatarsus; tt, tibiotarsus.
Other. NISP, number of individual specimens; MNI, minimum number of individuals.

Institutions. AM, Australian Museum, Sydney, Australia; SAM, South Australian Museum, South Australia; NMV, Museums Victoria, Victoria, Australia; NMNZ, Museum of New Zealand Te Papa Tongarewa, Wellington, New Zealand.

\section{Comparative Materials}

Skeletons from the South Australian Museum (SAM) and bones from the 2003 archaeological campaign, previously described by Worthy and Tennyson (2004), were used to identify the bones. Reference skeletons used in the identification of these bones are listed here.

Procellariiformes: Pterodroma heraldica NMNZ 0.24691; Pterodroma ultima NMNZ 0.24403; Pterodroma neglecta NMNZ 0.11423; Pterodroma phaeopygia sandwichensis NMNZ 0.22367; Pterodroma nigripennis NMNZ 0.13708, NMV B32632; Pterodroma leucoptera SAM B31271a; Puffinus pacificus NMNZ 0.27271, NMV B12741; Puffinus nativitatis NMNZ 0.19307; Puffinus gavia SAM B55367; Pseudobulweria rostrata, NMNZ 0.23900, 24691; Bulweria bulweria NMNZ O.22145. Charadriiformes: Anous stolidus NMNZ O.24593, O.25348, NMV B22237, Anous minutus NMNZ 0.24246, NMV B18451; Gygis alba NMNZ O.23894, O.23587, NMV B11025, 30907; Chlidonias leucopterus NMV B8969, Chlidonias hybrida NMV B55207, Thalasseus bergii NMNZ O.23879, NMV B30865; Pluvialis fulva NMV B20033.Phaethontidae: Phaethon rubricauda NMNZ 0.16056 , NMV B12819; Phaethon lepturus SAM B11476. Columbidae: Ducula spilorrhoa SAM B23902; Ducula goliath NMNZ 0.22839; Ducula galeata NMNZ O.26971; Ducula lakeba R tmt, cast of holotype, NMNZ S.38899; Ptilinopus regina SAM B37060, NMV B16328; Ptilinopus magnificus SAM B46569, NMV B20026; Gallicolumba beccarii NMV B20028; Alopecoenas stairi NMNZ S38223. Ardeidae: Egretta sacra SAM B.10999. Rallidae: Hypotaenidia (=Gallirallus) philippensis SAM B36299.

In addition, the columbid bones were compared with specimens from Teouma (Worthy et al., 2015), and the data reported for the Henderson Island taxa (Worthy and Wragg, 2003, 2008; Wragg and Worthy, 2006).

\section{Nomenclature}

We followed the taxonomic nomenclature in Dickinson and Remsen (2013). The procellariids that occur in the eastern tropical Pacific Ocean fall 
into three size classes; small, medium and large (e.g., Brooke, 1995a; Pyle et al., 2011).

Among small shearwaters, the Tropical Shearwater Puffinus bailloni dichrous, here including $P$. bailloni polynesiae of Tahiti, is recorded on islands across the Pacific from Palau and the Marianas to the Gambier Group (Thibault and Bretagnolle, 1999; del Hoyo et al., 2017) and is known to breed in the Tuamotu Archipelago (Thibault and Cibois, 2012; del Hoyo et al., 2017). However, several other small shearwaters either probably did or still do forage in the non-breeding period in the Tuamotu Archipelago, and in some cases may have formerly bred there, e.g., Puffinus bailloni gunax (breeding Vanuatu), Townsend's Shearwater $P$. auricularis myrtae (=P. newelli myrtae in del Hoyo et al. (2017); breeding on Rapa Island; BirdLife International 2017), and Little Shearwater Puffinus assimilis kermadecensis (Pyle et al., 2011; BirdLife International 2017; del Hoyo et al., 2017). Among larger shearwaters, the breeding range of Christmas Shearwater Puffinus nativitatis spans the tropical central and eastern Pacific, including the Gambier Group and the Pitcairn Islands (Brooke, 1995b; Thibault and Bretagnolle, 1999; del Hoyo et al., 2017). The Wedge-tailed Shearwater Ardenna pacifica is known to breed in the eastern Pacific (Marquesas) (Thibault and Cibois, 2012; del Hoyo et al., 2017), so can also be expected, if only as a visitor, in the Gambier Group.

This issue of multiple similar-sized co-occurring taxa is especially problematic among Pterodroma petrels. Minimally, five small taxa frequent the tropical eastern Pacific. Gould's Petrel Pterodroma leucoptera leucoptera (breeding on islands off the coast of New South Wales, Australia), P. leucoptera caledonica (breeding in New Caledonia), Collared Petrel P. brevipes (breeding in Fiji and Vanuatu), and Pycroft's Petrel P. pycrofti (breeding off Northland, in New Zealand), are all known to forage in this area (Dickinson and Remsen, 2013; Rayner et al., 2016; BirdLife International, 2017). Furthermore, P. leucoptera has unconfirmed breeding records from the Austral Islands and further east and Black-winged Petrel $P$. nigripennis, while breeding in the southwest Pacific, has a non-breeding range in the north and eastern Pacific (BirdLife International, 2017). Thus, all these small species of Pterodroma could occur in the Gambier Group on occasion.

Several medium-sized Pterodroma species breed in the eastern tropical Pacific (Pratt et al., 1987; Brooke, 1995; Thibault and Cibois, 2017), most of which are poorly represented in compara- tive recent skeleton collections, making specific identification of fragmentary bones difficult. These include Murphy's Petrel Pterodroma ultima, the Kermadec Petrel $P$. neglecta, and the slightly smaller Herald Petrel $P$. heraldica, all known to breed on islands in the southeast Tuamotu Archipelago, the Gambier Group, and the nearby Pitcairn Group (Thibault and Cibois, 2017). In addition, the Henderson Petrel $P$. atrata, while only known to breed on the Pitcairn Group (Brooke, 1995; Thibault and Cibois, 2017), is a potential vagrant to the Gambier Group. Similarly, the Phoenix Petrel $P$. alba, has a widespread breeding distribution in the eastern tropical Pacific, including the Marquesas and the Pitcairn Group (Thibault and Cibois, 2017), so vagrants to the Gambier Group would be expected. Given extinction has resulted in the loss of many breeding colonies of petrels since human colonisation, it is likely that more than one taxon each of small and medium petrels formerly bred in the Gambier Group, and certainly several would have and still do forage in the group. As noted by numerous authors, identification of petrels to genera based on skeletal elements is straightforward, but specific separation of congeneric similar-sized species, is often not possible on morphology alone (Wragg, 1995; Olson and Rasmussen, 2001; Tennyson et al., 2015). For example, Murphy and Pennoyer (1952: 1) noted that many of these species are so similar skeletally as to preclude their separation, stating "We have compared, for example, skulls of the species neglecta, arminjoniana, and ultima and can find no detail that would distinguish one from another." Identification is even more difficult with post cranial bones and is compounded by breakage as typifies archaeological deposits, and so specimens are often grouped into large, medium and small size groupings within genera (e.g., Murphy and Pennoyer, 1952; Walker et al., 1990; Wragg, 1995; Olson and Rasmussen, 2001; Cooper and Tennyson, 2008; Tennyson et al., 2015).

Given the diversity of similar-sized taxa either occurring or likely to have occurred in the Gambier Group region, we adopt a conservative approach and identify bones to genus and size categories as follows using the term magn. from the Latin magnitudino to indicate the approximate size of the bones in question without implying possible relationship, following Olson and Rasmussen (2001): Puffinus magn. P. bailloni (to include all small Puffinus taxa); Pterodroma magn. P. leucoptera (for small Pterodroma species); P. magn. P. heraldica (for mid-sized Pterodroma species). 


\section{SYSTEMATIC PALAEONTOLOGY}

Order GALLIFORMES Temminck, 1820

Family PHASIANIDAE Horsfield, 1821

Genus GALLUS Brisson, 1760

Gallus gallus (Linnaeus, 1758), Red Junglefowl

\section{Material}

Onemea Site (190-12-TAR-6), Taravai Is. (Total $\mathrm{NISP}=2 ; \mathrm{MNI}=2$ ).

Layer II: TAR6-TP10-II-2-20A, 1pR cor; $(\mathrm{NISP}=1$; $\mathrm{MNI}=1$ ).

Layer II/III: TAR6-TP10-II/III-3-28A-F, $1 \mathrm{R}$ cor; $(\mathrm{NISP}=1 ; \mathrm{MNI}=1)$.

Nenega-Iti Site (190-12-AGA-3), Agakauitai Is. (Total NISP=2; $\mathrm{MNI}=1$ ).

Layer IV: AGA3-G9-IV3-12-1-1J, 1pL scap; $(\mathrm{NISP}=1 ; \mathrm{MNI}=1)$.

Layer IV/V: AGA3-E9-IV/V-15-5-35, pt 1R fur; $(\mathrm{NISP}=1 ; \mathrm{MNI}=1)$.

The domestic junglefowl was first introduced by Polynesians to widespread islands in Eastern Polynesia (Southern Cook Islands - Marquesas Easter Island; data limited by archaeological investigation), but had gone extinct in the Gambier Group before European arrival (Green and Weisler, 2004; Thibault and Cibois, 2017). The extant population derives from a European reintroduction of junglefowl to the Gambier Group (Thibault and Cibois, 2017).

Order COLUMBIFORMES Latham, 1790

Family COLUMBIDAE Illiger, 1811

Genus BOUNTYPHAPS Worthy and Wragg, 2008

Bountyphaps sp. cf. B. obsoleta Worthy and Wragg, 2008 (Figure 2)

\section{Material}

Nenega-Iti Site (190-12-AGA-3), Agakauitai Is. (Total NISP $=1 ; \mathrm{MNI}=1$ ).

Layer IV: NMNZ S.47666, =AGA3-D9-IV4-21-5-1C, $1 \mathrm{dR}$ tt; (NISP=1; MNI=1).

Kitchen Cave (190-04-KAM-1), Kamaka Is. (Total $\mathrm{NISP}=4 ; \mathrm{MNI}=2$ ).

Layer V: KAM1-B3TP1-V-3A-B, $1 \mathrm{dR}$ ulna; $(\mathrm{NISP}=1 ; \mathrm{MNI}=1)$

Layer VI: KAM1-B3TP1-VI-4A-F, 1sL ulna, 1sL tt, 1sL tmt (NISP=3; MNI=1).

\section{Measurements}

AGA3-D9-IV4-21-5-1C, dR tibiotarsus: distal width $8.9 \mathrm{~mm}$, depth medial condyle $9.4 \mathrm{~mm}$, depth of lateral condyle $8.2 \mathrm{~mm}$. KAM1-B3TP1-V-3A-B, $\mathrm{dR}$ ulna: shaft width $3.3 \mathrm{~mm}$; maximum distal width $>6.2 \mathrm{~mm}$ (tuberculum carpale broken). KAM1-
B3TP1-VI-4A-F, distal shaft $\mathrm{L}$ tarsometatarsus, minimum shaft width proximal to metatarsal facet $3.85 \mathrm{~mm}$.

Comments. The tibiotarsus NMNZ S.47666 (Figure 2) from Nenega-Iti is referred to Bountyphaps and tentatively to $B$. obsoleta, described from Henderson Island, as it has the following unique combination of diagnostic features of that taxon (Wragg, 2008). 1) The medial tuberosity for the proximal attachment of the retinaculum extensorium tibiotarsi (ptRET) is prominent and is separated from the condylus medialis by a distance much less than the height of the medial condyle; 2) the distal attachment point for the retinaculum extensorium tibiotarsi (dtRET) is prominent and adjacent to the pons supratendineus; 3 ) the lateral margin of the sulcus extensorius proximal to the pons supratendineus is rounded, not with a sharp crest; 4) the medial attachment point for the retinaculum $\mathrm{m}$. fibularis (mtRMF) laterad of the sulcus extensorius is poorly marked; 5 ) the lateral attachment for the retinaculum $\mathrm{m}$. fibularis (ItRMF) is on the lateral facies and is aligned anterocaudally rather than parallel to the shaft; 6) a small (not large) foramen penetrates the corpus cranially close to the proximal margin of the condylus lateralis; 7) the distal width across the condyles is narrower caudally than cranially; 8 ) the depth of the condylus medialis is greater than the distal condylar width; and 9) the epicondylaris medialis is prominent and visible in cranial view. The size of NMNZ S.47666 from Agakauitai Island, Gambier Group, is intermediate between that of the two tibiotarsi of Bountyphaps obsoleta described by Worthy and Wragg (2008) from Henderson Island and greater than those of Alopecoenas ( $=$ Gallicolumba) leonpascoi from that island $(\mathrm{DW}=7.5-7.8 \mathrm{~mm}$; Worthy and Wragg, 2003). Note, Alopecoenas includes taxa in the Central and Eastern Pacific formerly listed in Gallicolumba, so extinct species erected in this genus and from this region are hereafter placed in Alopecoenas. Tibiotarsi of Alopecoenas nui differ with a markedly prominent mtRMF (4) forming a crest up the lateral side of the sulcus extensorius just proximal to the pons supratendineus; a markedly laterally prominent ItRMF (5) forming a bulge in the lateral margin in cranial aspect and in lacking a prominent epicondylus medialis (8), in addition to their smaller size.

The dR ulna (KAM1-B3TP1-V-3A-B) from Layer V, Kitchen Cave, is referred to Bountyphaps sp. cf. B. obsoleta because it differs from other likely candidate species as follows: from species of Ducula, by the more widely separated papilla 

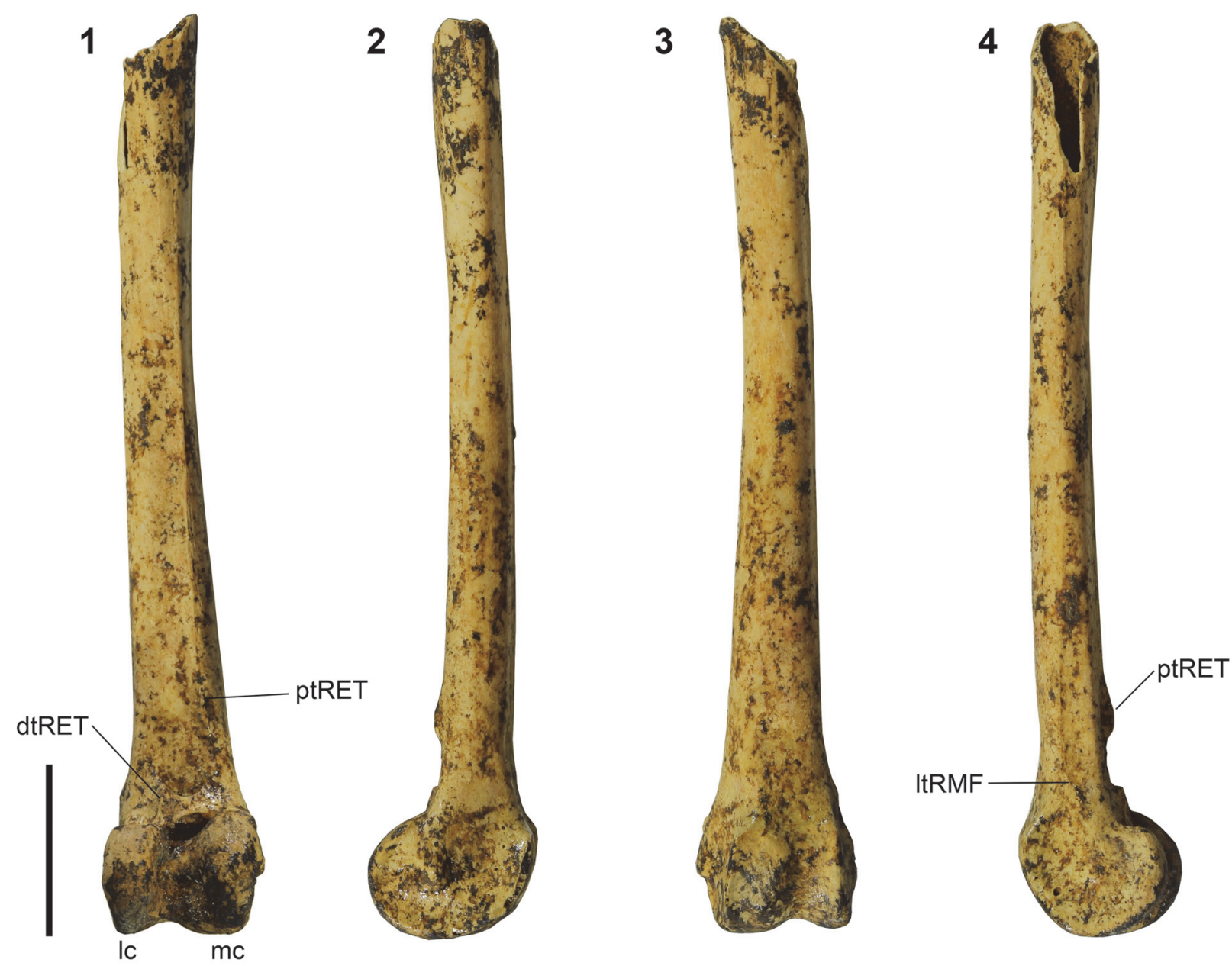

FIGURE 2. The distal right tibiotarsus NMNZ S.47666 from Nenega-Iti that is referred to Bountyphaps obsoleta, in cranial (1), medial (2), caudal (3) and lateral (4) views. Abbreviations: dtRET, distal attachment of the retinaculum extensorium tibiotarsi; Ic, condylus lateralis; ItRMF, lateral attachment of the retinaculum musculus fibularis; mc, condylus medialis; ptRET, proximal attachment of the retinaculum extensorium tibiotarsi. Scale bar equals $10 \mathrm{~mm}$.

remiges; from species of Ptilinopus, by greater size than all except $P$. magnificens of Australia; and from most species of Alopecoenas by larger size. Alopecoenas leonpascoi of nearby Henderson Island (Worthy and Wragg, 2003), was one of the larger species in this genus, and had a much smaller and slenderer ulna (shaft width of 2.5-2.6 $\mathrm{mm}$, vs $3.3 \mathrm{~mm}$ ). Larger species than A. leonpascoi are known, notably $A$. nui from the Marquesas (Steadman, 1992), and provisionally from the Cook Islands (Steadman, 1997), but available descriptions do not include ulnae measurements. However, the size $A$. nui may be assessed from the recorded distal width measurements for tibiotarsi (7.6-8.4 mm), which do not differ greatly from those for A. leonpascoi (7.5-7.8 mm; Worthy and Wragg,
2003). Given the ulna from Kitchen Cave is much larger than those of $A$. leonpascoi (maximum DW = 4.6-4.9 and $\mathrm{SW}=2.5-2.6 \mathrm{~mm}$; Worthy and Wragg, 2003), it is unlikely to be from $A$. nui.

Three other fragmentary columbid bones derive from among burnt bone material from layer VI (KAM1-B3TP1-VI-4A-F). The ulna lacks either end, but the rebuilt shaft section distally overlaps part of the specimen KAM1-B3TP1-V-3A-B and is very similar in size and morphology. It shows that overall the ulna is slenderer than those of species of Ducula. The associated shaft of a tibiotarsus is smaller than the specimen referred to Ducula from Onemea and similar to NMNZ S.47666 referred to Bountyphaps from Nenega-Iti. The shaft of the left tarsometatarsus differs greatly from those of spe- 
cies of Ducula by having an elongated mid-section. It is more like those of Didunculus placopedetes, e.g., L tarsometatarsus, Australian Museum AM138761, in the arrangement of the metatarsal facet and the cristae plantares medialis et lateralis, although the metatarsal facet is medially-prominent in dorsal view (not so in D. placopedetes) and the medial crista on the dorsal facies is farther from the medial margin. An elongate shaft also characterises species of Alopecoenas and the Kamaka Island specimen is within the size range of Alopecoenas nui (Marquesas), see Steadman (1992), but is larger than Alopecoenas leonpascoi (Pitcairn Group), which has a shaft width of 3.6-3.7 mm (Worthy and Wragg, 2003). However, Bountyphaps obsoleta (Pitcairn Group) is larger than A. leonpascoi and of similar size to $A$. nui and is more similar to species of Didunculus than other taxa (Worthy and Wragg, 2008), so while a tarsometatarsus is unknown for $B$. obsoleta, it predictably would be elongate like those of species of Didunculus. Moreover, while this is only a shaft fragment it has cristae-like dorsal lineae intermusculari at the level of the fossa metatarsi I, with the medial line enclosing a shallow groove between it and the facet in that fossa, which is strongly developed and protrudes medial to the shaft. In both $A$. leonpascoi and in $A$. stairi, the dorsal lineae intermusculari are much weaker and the facet in fossa metatarsi I barely projects medially (Worthy and Wragg, 2003). Given the tibiotarsus and ulna can both be referred to Bountyphaps with some confidence and tentatively to $B$. obsoleta from Henderson Island some 540 $\mathrm{km}$ distant, we consider it most parsimonious to refer the tarsometatarsus from the same site to the same taxon. We think it less likely that two relatively similar taxa would coexist in the Gambier Group, as a referral of the tarsometatarsus to Alopecoenas nui, otherwise known from 1500 km distant in the Marquesas would infer.

Steadman and Justice (1998), repeated in Steadman (2006), referred a humeral end of a coracoid and a shaft of a tibiotarsus from Kamaka Island to Alopecoenas nui, which taxon was originally described from the Marquesas, but this was before $A$. leonpascoi from the Pitcairn Group was known (Worthy and Wragg, 2003). This latter species, while slightly smaller than $A$. nui, is also relatively large for the genus and attests to a diversity of big species of Alopecoenas across the CentralEastern Pacific. Moreover, Bountyphaps obsoleta, a similarly large taxon, also from the Pitcairn Group, but with affinities to the long-legged Didunculus-group (Worthy and Wragg, 2008), was also then unknown, and so both Alopecoenas and Bountyphaps, or close relatives, could be expected in the Gambier Group, which is the nearest significant land to Henderson Island. The measurements in Steadman and Justice (1998) do not distinguish the Kamaka Island specimens from either $B$. obsoleta or A. leonpascoi, and these authors did not figure them. Descriptions were limited to a statement that they do not differ from those of $A$. nui and some observations of muscular linea on the tibiotarsus shaft, which in-so-far as they can be compared, match what is seen on the bone referred above to $B$. obsoleta from Nenega-Iti. Given, the most diagnostic columbid bone from Kamaka Island from one of these taxa that we report herein is the distal tibiotarsus, and it does not differ from that of $B$. obsoleta, we consider the bones Steadman and Justice (1998) reported are most likely of this taxon. Even if they were truly a species of Alopecoenas, then it is more likely that they would be from $A$. leonpascoi, given the much closer proximity (540 versus $1500 \mathrm{~km}$ ) of its type locality on Henderson Island to the Gambier Group. Until, the specimens from Kamaka Island that Steadman and Justice (1998) referred to $A$. nui are compared with $B$. obsoleta and $A$. leonpascoi, their identification as being referrable to the Marquesan species $A$. nui must be considered doubtful.

\section{Genus DUCULA Hodgson, 1836}

The following specimens are referred to a species of Ducula because they have the following diagnostic features (Worthy, 2001; Wragg and Worthy, 2006; Worthy and Wragg, 2008). Tarsometatarsus: 1) has similar proportions to other members of the genus; 2) the cotyla medialis in medial view is projected dorsally; 3 ) the medial foramen of the foramina vascularia proximalia is elongate and much larger than its lateral equivalent; 4) the foramina vascularia proximalia are widely separated by a low ridge and lie in a sulcus bound by prominent ridges; 5) the foramen vasculare proximale medialis lies close (less than the foramen width) to the medial edge of the shaft; 6 ) the tuberositas $\mathrm{m}$. tibialis cranialis is distal to the foramen vasculare proximale medialis in the sulcus extensorius and so is close to the medial margin; 7 ) the lateral profile of the shaft leading to trochlea metatarsi IV is slightly concave. Tibiotarsus: 8 ) the medial tuberosity for the proximal attachment of the retinaculum extensorium tibiotarsi (ptRET) is prominent and is separated from the condylus medialis by a distance greater than the proximodistal height of the medial condyle; 9) the distal attachment point for the retinaculum extensorium 
tibiotarsi (dtRET) is a marked prominence on the lateral side of the sulcus extensorius proximal to the pons supratendineus; 10) the lateral margin of the sulcus extensorius proximal to the pons supratendineus is bound by a sharp crest; 11) the medial attachment point for the retinaculum $\mathrm{m}$. fibularis (mtRMF) laterad of the sulcus extensorius is poorly marked; 12) the lateral attachment of the retinaculum $\mathrm{m}$. fibularis (ItRMF) is on the lateral facies and is aligned parallel to the shaft; 13) it lacks a foramen penetrating the corpus cranially close to the proximal margin of the condylus lateralis; 14) the distal width across the condyles is about the same caudally and cranially; 15) the depth of the condylus medialis is about equal to the distal condylar width.

The tibiotarsus and tarsometatarsus differ from those of known species of Ducula, so they are described as a new taxon. The remaining bones are referred to the same new species because they are of appropriate size and were found in close proximity to the above elements and no other similarly large columbid species was represented in the site.

\section{Ducula tihonireasini nov. sp. (Figure 3)}

zoobank.org/BF74BA36-4198-4F84-8D97-99929D504084

\section{Holotype}

NMNZ S.47667, field number TAR6-TP02-II-5-20, right tarsometatarsus, broken through the foramen distale and lacking all trochleae (Figure 3.1-3.4), collected by P. Kirch et al., 19 August 2003.

\section{Holotype Locality}

Layer II, level 5, test pit 2, Onemea Dune Site (19012-TAR-6), Taravai Island, Gambier Group, French Polynesia (Conte and Kirch, 2004; Kirch et al., 2010).

\section{Paratype}

NMNZ S.47668, field number TAR6-TP11-3-19AC, dR tibiotarsus (Figure 3.5-3.8), collected by P. Kirch et al. August 2005.

\section{Paratype Locality}

Layer II, level 3, test pit 11, Onemea Dune Site (190-12-TAR-6), Taravai Island, Gambier Group, French Polynesia (Kirch et al., 2010).

\section{Diagnosis}

A species of Ducula with tibiotarsi and tarsometatarsi smaller than those of the extinct Ducula lakeba of Fiji, $D$. david of Uvea, $D$. harrisoni of Henderson Island and the extant $D$. goliath of New
Caledonia and $D$. galeata of the Marquesas, but larger than all other species east of the Solomon Islands (Worthy, 2001; Wragg and Worthy, 2006). The tarsometatarsus is robust with similar proportions to that of $D$. david from Uvea (Balouet and Olson, 1987), as defined by maximum shaft width across the articular facet in fossa metatarsi I as a proportion of length, and is more robust than those of other large species such as $D$. galeata, $D$. harrisoni and D. lakeba (Worthy, 2001; Worthy and Wragg, 2008). The fossa parahypotarsalis medialis separated from the fossa metatarsi I. Dorsal facies with very well marked lineae intermusculari, one medially, one laterally and one intermediate.

\section{Etymology}

The species is named after the late Tihoni Reasin, who was the owner of Kamaka Island. Tihoni, as a 14-year old, worked with Roger Green in the first excavation of Kitchen Cave. He then greatly assisted PV Kirch and his team in all of their field trips to Mangareva, and especially during the 2012 and 2014 re-excavations at Kitchen Cave, when he hosted them on Kamaka.

\section{Stratigraphy/Age}

An archaeological deposit deposited between AD 950 and AD 1350 (Kirch et al., 2010).

\section{Referred Material}

Onemea Dune Site (190-12-TAR-6). Total, including types, $\mathrm{NISP}=6 ; \mathrm{MNI}=3$.

Layer II: TAR6-TP02-II-5-20, pL fem; TAR6-TP11II-2-9A-D, L metatarsal. Both specimens were in the same layer and in the same (TP2 - holotype) or adjacent (TP11-paratype) excavated units as the type material.

Layer II: TAR6-TP05-II-6-55A-H, sR tt, which overlaps the shaft area preserved in the paratype NMNZ S.47668, is from a second individual, (Total Layer II, including types, $\mathrm{NISP}=5 ; \mathrm{MNI}=2$ ).

Layer III: TAR6-TP02-II-8-33-F, L manus phalanx II. 1 (Total NISP= 1; MNI = 1).

\section{Measurements}

Holotype. NMNZ S.47667 (TAR6-TP02-II-5-20), tarsometatarsus, length from proximal end to foramen vasculare distale $33 \mathrm{~mm}$, length to distal side of the metatarsal facet $24.1 \mathrm{~mm}$, length from posterior edge cotyla medialis to proximal end of fossa metatarsi 1 (length 2 - Wragg and Worthy, 2006) $20.1 \mathrm{~mm}$, length from posterior edge cotyla medialis to distal end of medial prominence of fossa metatarsi 1 (length 3 - Wragg and Worthy, 2006) 
1
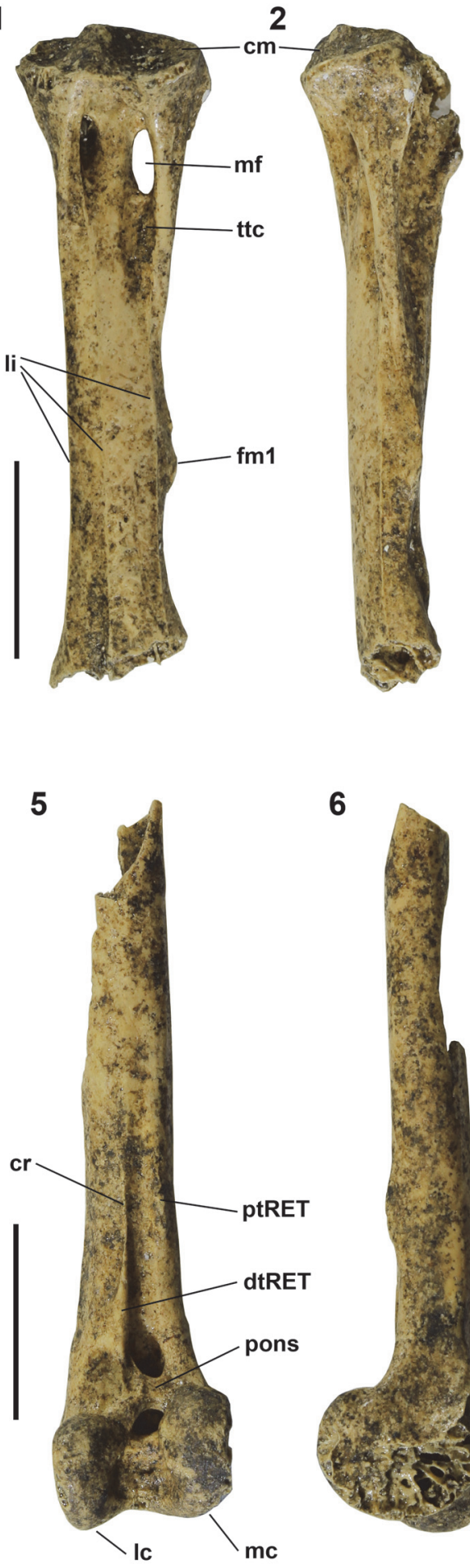

6
3

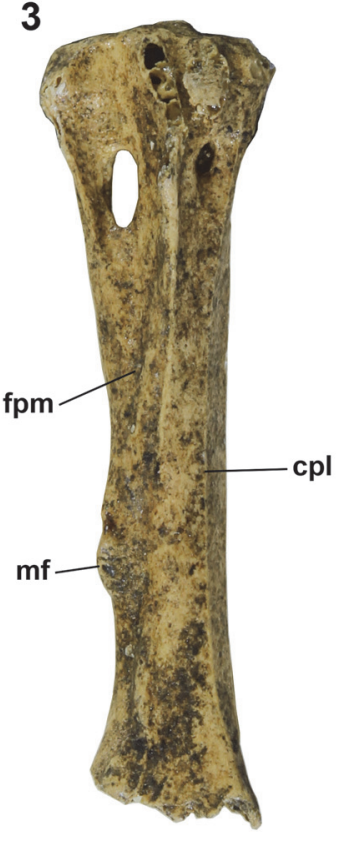

4

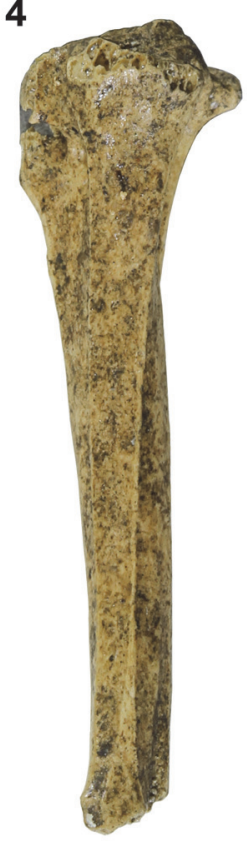

7

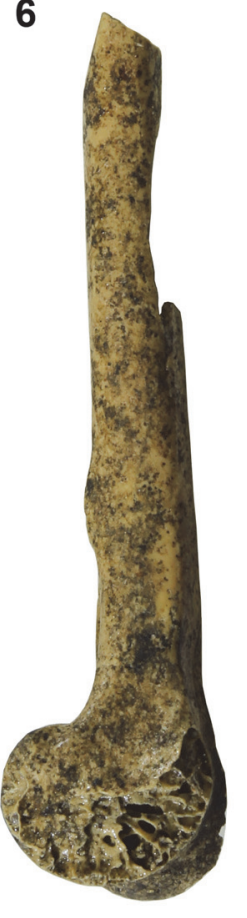

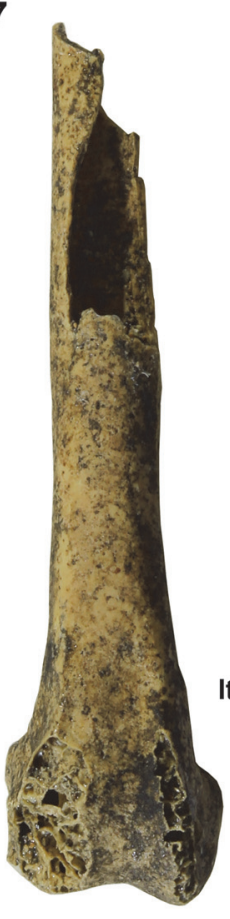

8

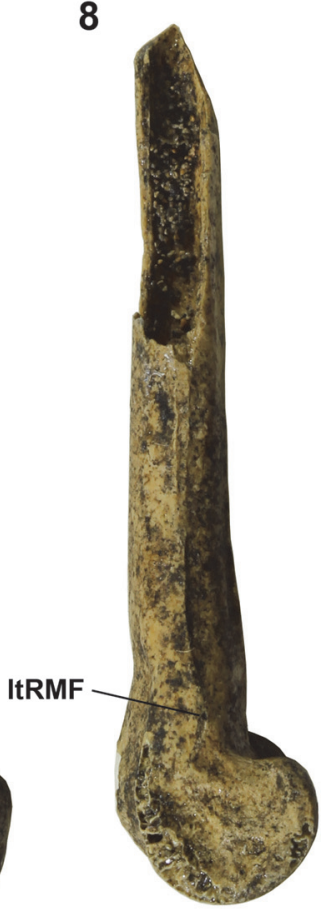

FIGURE 3. Ducula tihonireasini n.sp., holotype right tarsometatarsus NMNZ S.47667 (1-4) and paratype distal right tibiotarsus NMNZ S.47668 (5-8) in cranial $(1,5)$, medial $(2,6)$, plantar/caudal $(3,7)$ and lateral $(4,8)$ views. Abbreviations: $\mathbf{~ c m}$, cotyla medialis; $\mathbf{c p l}$, crista plantaris lateralis; $\mathbf{c r}$, crest; $\mathbf{d t R E T}$, distal attachment of the retinaculum extensorium tibiotarsi; $\mathbf{f m 1}$, facet in fossa metatarsi 1 ; fpm, fossa parahypotarsalis medialis; Ic, condylus lateralis; li, lineae intermusculari; ItRMF, lateral attachment of the retinaculum musculus fibularis; mc, condylus medialis; mf, medial foramen vasculare proximale; pons, pons supratendineus; ptRET, proximal attachment of the retinaculum extensorium tibiotarsi; ttc, tuberositas musculus tibialis cranialis. Scale bar equals $10 \mathrm{~mm}$. 
$24.0 \mathrm{~mm}$, proximal width $9.6 \mathrm{~mm}$, depth cotyla medialis $5.9 \mathrm{~mm}$, least shaft width distal to metatarsal facet $4.6 \mathrm{~mm}$, width at metatarsal facet $5.3 \mathrm{~mm}$. Paratype. NMNZ S.47668 (TAR6-TP11-3-19A-C), tibiotarsus, distal width $8.9 \mathrm{~mm}$, depth of condylus lateralis $7.4 \mathrm{~mm}$; depth of condylus medialis 8.7 $\mathrm{mm}$; shaft width at the medial tuberosity for the proximal attachment of the retinaculum extensorium tibiotarsi $4.3 \mathrm{~mm}$.

Referred material. TAR6-TP02-II-5-20, pL fem, proximal width $9.4 \mathrm{~mm}$, proximal depth $8.2 \mathrm{~mm}$; TAR6-TP11-II-2-9A-D, L metatarsal, total length $11.2 \mathrm{~mm}$, maximum distal width $6.3 \mathrm{~mm}$, length of articular facet $8.0 \mathrm{~mm}$; TAR6-TP05-II-6-55A-H, sR $\mathrm{tt}$, preserved length $45 \mathrm{~mm}$, least shaft width 4.5 $\mathrm{mm}$, width at distal end of crista fibularis $6.6 \mathrm{~mm}$, length of crista fibularis $14.5 \mathrm{~mm}$; TAR6-TP02-II-833-F, L manus phalanx II.1, total length $23.8 \mathrm{~mm}$, articular length $21.4 \mathrm{~mm}$, width at distal end level with articular surface $7.2 \mathrm{~mm}$.

\section{Description and Comparisons}

In addition to the diagnostic features listed above, we note other features that distinguish Ducula tihonireasini $\mathrm{n}$. sp. from its geographically closest congener, $D$. harrisoni of Henderson Island, which has larger and more gracile tarsometatarsi. The dorsal lineae intermusculari form elevated cristae along their length and are much more prominent than those on $D$. harrisoni, see Wragg and Worthy (2006). The one on the medial margin connects the tuberositas $\mathrm{m}$. tibialis cranialis and trochlea metatarsi II. The lateral linea, in dorsal aspect, forms a straight crest extending along the margin distal to the lateral foramen vasculare proximale onto the dorsal surface of trochlea metatarsi IV where it diverges from the shaft. The middle linea commences by defining the lateral margin of the lateral foramen vasculare proximale, then extends distally as the dorsal crest of the dorsal facies to pass on the medial side of the foramen vasculare distale. All three lineae are much more weakly marked on the Henderson D. harrisoni. Plantarly, the crista plantaris lateralis in $D$. tihonireasini is more strongly developed. Ducula harrisoni further differs from $D$. tihonireasini by greater separation of fossa parahypotarsalis medialis from fossa metatarsi I. The fossa metatarsi I is deeper in Ducula tihonireasini and includes a discrete sulcus just distal to the facet for articulation of the os metatarsale. Also, this facet is relatively larger and extends beyond the medial shaft margin to a greater extent. The only species with a similarly stout shaft is $D$. david, however, in this species the fossa parahy- potarsalis medialis is relatively larger and distally abuts the fossa metatarsi I (Wragg and Worthy, 2006).

Ducula galeata has a far more slender tarsometatarsus, with NMNZ 0.26971 having greater length and proximal width values, but substantially narrower shaft width values as follows (those of $D$. tihonireasini in brackets for comparison): length from proximal end to foramen vasculare distale $34.6 \mathrm{~mm}$ (33.0), length to distal side of the metatarsal facet $26.7 \mathrm{~mm}$ (24.1), length from posterior edge cotyla medialis to distal end of medial prominence of fossa metatarsi $125.0 \mathrm{~mm}$ (18.0), proximal width $10.8(9.6 \mathrm{~mm}) \mathrm{mm}$, least shaft width distal to metatarsal facet $3.6 \mathrm{~mm}(4.6 \mathrm{~mm})$, width at metatarsal facet $4.1 \mathrm{~mm}(5.3 \mathrm{~mm})$. The tibiotarsus of $D$. galeata has greater distal width $(10.2 \mathrm{~mm})$ but a similar shaft width $(4.4 \mathrm{~mm})$, consistent with $D$. tihonireasini having a relatively stout shaft as the measurements of the tarsometatarsus would predict. However, but $D$. tihonireasini differs further with much more robust attachment points for the retinaculum extensorium tibiotarsi and thus a deeper sulcus extensorius.

\section{Comments}

Within the clade of frugivorous pigeons, there were in the prehuman period very often three sizeclasses in an archipelago, a small Ptilinopus fruit dove, and medium- and large-sized species of imperial pigeons in the genus Ducula, e.g., D. pacifica and $D$. goliath. However, recent phylogenetic analyses of molecular data have shown that the larger species of Ducula do not form a clade and have evolved repeatedly from smaller relatives (Cibois et al., 2017). The size classes shown by fruit pigeons doubtless reflect niche segregation based on the size of fruit that can be swallowed (Meehan et al., 2002). The only surviving large species of Ducula are D. goliath on New Caledonia and $D$. galeata in the Marquesas. However, in the huge intervening area between where these taxa live, there once occurred numerous other large, now extinct, species or populations that could disperse fruit larger than $28 \mathrm{~mm}$ in diameter, which is the maximum that $D$. pacifica can eat (Meehan et al., 2002; Steadman, 2006). These include Ducula sp. cf. D. goliath on Efate in Vanuatu (Worthy et al., 2015), an undescribed Ducula sp. on Viti Levu and $D$. lakeba in the Lau Group, Fiji (Worthy, 2001), an undescribed species from Rapa Island in the Austral Group (Tennyson and Anderson, 2012), $D$. david on Uvea in Wallis and Futuna (Balouet and Olson, 1987), an undescribed Ducula sp. on 
several islands in Tonga (Steadman, 1989b, 1993 [as $D$. david], 1995, 1997, 2006), extirpated populations referred to $D$. galeata on Mangaia in the Cook Islands and Huahine in the Society Islands (Steadman, 1989a, b, 1995, 1997, 2006), and D. harrisoni on Henderson Island (Wragg and Worthy, 2006). The discovery here of another large species of Ducula in the Gambier Group reinforces the idea that there has been parallel evolution of large forms on many of the islands or archipelagos of the Pacific (Worthy et al., 2015). Furthermore, given the presence of distinct large species of Ducula on Henderson Island and in the Gambier Group, then the identification of fossils from the Society and Cook Islands as $D$. galeata (extant only in the Marquesas) may need revisiting, as their identification as a similarly large but distinct species of Ducula may be more likely.

It is possible that Ducula tihonireasini survived into the Historic period, given the old accounts reported by Thibault and Cibois $(2012,2017)$ of a "wood-pigeon" (Beechey, 1832) and a "ramier" (Lesson, 1844).

Genus PTILINOPUS Swainson, 1825 Ptilinopus sp. indet., indeterminate fruit dove

\section{Material}

Onemea Site (190-12-TAR-6), Taravai Is. (Total $\mathrm{NISP}=3 ; \mathrm{MNI}=3$ ).

Layer II: TAR6-TP11-II-6-38A-B, dR tmt; (NISP=1; $\mathrm{MNI}=1$ ).

Layer III: TAR6-TP10-III-5-35A-E, 2dL tt; (NISP=2; $\mathrm{MNI}=2$ ).

\section{Comments}

A mere three fragmentary specimens attest to the former presence of Ptilinopus doves in the Gambier Group. The dR tmt preserves only the area distal to the facet in the fossa metatarsi I, which with a length of $10.2 \mathrm{~mm}$ is of a bird a bit larger than $P$. regina. It also lacks all the plantar part of trochlea metatarsi II and all of trochlea metatarsi IV, but has a least shaft width of $2.3 \mathrm{~mm}$ and an estimated distal width of about $5.6 \mathrm{~mm}$. Similarly, the two distal tibiotarsi fragments, which lack the condyles and preserve the pons supratendineus and some shaft proximal to that, indicate a dove a bit larger than $P$. regina. They are identified as of a species of Ptilinopus by general resemblance to, for example, P. regina, and especially by the locations of the attachment points for the retinaculum extensorium tibiotarsi. The proximal attachment point (ptRET) is prominent and lies far proximal to the condylus medialis. The distal attachment point (dtRET) is a narrow, very elongate and prominent crest, extending from the pons supratendineus proximally along the margin of the sulcus extensorius.

The small columbid Alopecoenas erythroptera, extant in the nearby Tuamotu Archipelago, was possibly present on the Gambier Group in the nineteenth century (Thibault and Cibois, 2012, 2017) and was recorded from Kamaka Island based on a humerus (Steadman and Justice, 1998). The distal width of the tarsometatarsus in this species is 6.9-7.2 mm (Steadman, 1992) so is larger than the specimen recorded here. Furthermore, the Onemea tarsometatarsus is similar to species of Ptilinopus in having the facet in fossa metatarsi I located well proximal to the foramen vasculare distale; the facet lies much closer to the distal end in species of Alopecoenas.

Thibault and Cibois (2012) reported a species of Ptilinopus based on Kirch et al.'s (2010: 75) statement that "David Steadman.... noted the rare presence of 4 bones of pigeon, 3 bones of fruit dove...". The latter are the three specimens reported here. Thibault and Cibois (2012) noted that several visitors recorded a probable fruit dove during the nineteenth and early twentieth centuries, but that no specimen was known to have been collected. Species of Ptilinopus survive in the Tuamotu Archipelago (P. chalcurus, $P$. coralensis), the Marquesas ( $P$. dupetithouarsii, $P$. mercierii) and Henderson Island ( $P$. insularis) so a former presence of this genus in the Gambier Group is to be expected.

COLUMBIDAE genus et sp. indet.

\section{Material}

Kitchen Cave (190-04-KAM-1), Kamaka Is. (Total $\mathrm{NISP}=3 ; \mathrm{MNI}=1)$.

Layer VI: KAM1-B3TP1-VI-16-2A, L cmc; KAM1B3TP1-VI-16-4A-D, sR hum; KAM1-B3TP1-VI-171A-F, R scap; (NISP=1; MNI=1).

Of these bones, the carpometacarpus is potentially the most diagnostic. It is $29.2 \mathrm{~mm}$ long and has a large cranially-directed processus extensorius, whereon the proximal margin is at right angles to the bone axis, except for a slight proximal projection at its tip. It has a large and ventrallyprominent processus pisiformis, the ventral rim of the trochlea carpalis is rather short, terminating distally level with the tip of the processus extensorius, and the processus intermetacarpalis is small and in the proximal half of the spatium intermetacarpalis. The carpometacarpus attributed to Bountyphaps obsoleta by Worthy and Wragg (2008) is 
longer $(33.8 \mathrm{~mm})$, and the ventral rim of the trochlea carpalis is longer, extending distally beyond the processus extensorius. However, it is similar in that the processus extensorius is not directed proximally, the trochlea carpalis lacks a fossa infratrochlearis ventrally, and the processus intermetacarpalis is in a similar location (Worthy and Wragg, 2008, figure 2A). KAM1-B3TP1-VI-16$2 \mathrm{~A}$ also differs markedly from carpometacarpi of Alopecoenas species, which are characterised by a strongly proximally-directed processus extensorius, and are smaller, even in the large $A$. leonpascoi (length 21.9-24.2 mm; Worthy and Wragg, 2003). Species of Didunculus are also characterised by a proximally directed processus extensorius, but tend to have a distally short ventral rim of trochlea carpalis (Worthy and Wragg, 2008, figure 2 ). This carpometacarpus is much too small to be associated with the species of Ducula recorded from Teouma, and too large to be associated with the Ptilinopus bones.

It is possible that KAM1-B3TP1-VI-16-2A, represents a species of Macropygia. Steadman (1992) described the relatively large and extinct cuckoo doves $M$. arevarevauupa from Huahine, Society Islands, and $M$. heana from the Marquesas. The latter had carpometacarpi that ranged in length 28.0-29.6 mm, so are of appropriate size for the Kamaka pigeon, but were not described or figured by Steadman (1992). However, M. amboinensis, e.g., AM 0.70775 , differs from the fossil with a more elongate ventral rim of the trochlea carpalis, a more proximally directed processus extensorius and the os metacarpale minus extending distal to os metacarpale majus (equal in the fossil). In summary, this carpometacarpus has features that preclude its attribution to Bountyphaps and it is of an appropriate size to be a species of Macropygia. Whatever its relationships, it represents a fourth species of pigeon for the Gambier Group.

Of the remaining bones, the scapula is of appropriate size to be associated with the bones identified as Bountyphaps sp. cf. B. obsoleta but is not so identified because columbid scapulae are poorly diagnostic. The humeral shaft is of appropriate size to be associated with the carpometacarpus, but is too incomplete to inform on relationships.

\footnotetext{
Order PHAETHONTIFORMES Sharpe, 1891

Family PHAETHONTIDAE Brandt, 1840

Genus PHAETHON Linnaeus, 1758

Phaethon lepturus Daudin, 1802, White-tailed Tropicbird
}

\section{Material}

Onemea Site (190-12-TAR-6), Taravai Is. (Total $\mathrm{NISP}=20 ; \mathrm{MNI}=4)$.

Layer II: TAR6-TP05-II-2-25A-C, 1dL ulna; TAR6TP05-II-5-45A-D, 1L cmc; TAR6-TP05-II-6-55A-D, 1dL cmc; TAR6-TP06-II-2-19A-D, 1dL rad; TAR6TP06-II-4-36A-B, 1pR1dR 1L1pL ulna, 1pR1L rad, 1R cmc; TAR6-TP06-II-4-37A-C, 2R cmc, 1dR rad, $1 \mathrm{dR} 1 \mathrm{dL}$ hum; TAR6-TP10-II-2-13A, 1sR ulna; $(\mathrm{NISP}=17 ; \mathrm{MNI}=3$ ).

Layer III: TAR6-TP06-III-1-58A-B, 1R cmc; TAR6TP10-III-4-29A-C, 1dR hum; TAR6-TP11-III-2-65AA, 1dL hum; (NISP=3; MNI=1).

Nenega-Iti Site (190-12-AGA-3), Agakauitai Is. (Total NISP $=5 ; \mathrm{MNI}=2$ ).

Layer IV: AGA3-F9-IV3-12-8-1H, 1pL cmc; AGA3F9-IV3-12-8-1M, 1dL ulna; AGA3-F9-IV3-12-8-1T, $1 \mathrm{dR}$ rad; AGA3-G9-IV3-12-1-1D, 1pR rad; AGA3G9-IV3-12-1-1F, 1R cmc; (NISP=5; MNI=2).

Kitchen Cave (190-04-KAM-1), Kamaka Is. (Total $\mathrm{NISP}=8 ; \mathrm{MNI}=5$ ).

Layer II: KAM1-B2-II-2-1-31D, 1R phal II.1; $(\mathrm{NISP}=1 ; \mathrm{MNI}=1)$.

Layer III: KAM1-B3TP1-III2-6-8A-B, 1 anterior pmx; KAM1-B3TP1-III2-7-5A-A, 1dR cor; KAM1B3TP1-III2-7-5A-E, 1pL rad; KAM1-B4-III2-7-9-1C, $1 \mathrm{pL}$ ulna; (NISP=4; $\mathrm{MNI}=1)$.

Layer IV: KAM1-B4-IV1-10-3-1B, 1pL tt; KAM1-C4IV2-13-4-39B, 1pL rad; (NISP=2; $\mathrm{MNI}=2$, allowing for sub-layers).

Layer V: KAM1-C3-V-15-6-25B, 1dL tt; $(\mathrm{NISP}=1$; $\mathrm{MNI}=1$ ).

The Gambier Group is one of the most southern breeding places for this species, which lives in tropical-sub-tropical waters of the Atlantic, Indian and Pacific oceans.

\section{Phaethon rubricauda Boddaert, 1783 Red-tailed Tropicbird}

\section{Material}

Onemea Site (190-12-TAR-6), Taravai Is. (Total $\mathrm{NISP}=9 ; \mathrm{MNI}=3$ ).

Layer II: TAR6-TP05-II-6-55A-B, $1 \mathrm{~L}$ tt, 1dL rad; TAR6-TP06-II-1-13A-B, 1sL ulna; (NISP=3; $\mathrm{MNI}=1)$.

Layer III: TAR6-TP02-III-8-33-E, juv 1R1L fem; TAR6-TP02-III-8-35-E, $1 \mathrm{~L}$ tmt; TAR6-TP02-III-939-H, 1L cor, 1L scap; (NISP=5; MNI=1).

Unknown (Layer X): TAR6-TP10-X-St.1-34A-E, $1 \mathrm{dR}$ hum; (NISP=1; MNI=1).

Kitchen Cave (190-04-KAM-1), Kamaka Is. (Total $\mathrm{NISP}=1 ; \mathrm{MNI}=1$ ). 
Layer III: KAM1-C4-III2-8-4-41A, $1 \mathrm{pL}$ rad; $(\mathrm{NISP}=1 ; \mathrm{MNI}=1)$.

While this taxon breeds at widespread locations in Eastern Polynesia, it does not breed regularly in the Gambier Group nowadays (Thibault and Cibois, 2017).

Order PROCELLARIIFORMES Fürbringer, 1888 Family PROCELLARIIDAE Leach 1820 Genus PSEUDOBULWERIA Mathews, 1936 Pseudobulweria sp. indet.

\section{Material}

Onemea Site (190-12-TAR-6), Taravai Is. (Total $\mathrm{NISP}=158 ; \mathrm{MNI}=26)$.

Layer I: TAR6-TP11-I-1-3A-B*, pR fem; TAR6TP03-I-2-4A-B*, dR tt; TAR6-TP05-I-1-1A-A*, dR tt; TAR6-TP06-I-1-2A-B ${ }^{*}, \quad p R \quad$ fem; $\quad(N I S P=4$; $\mathrm{MNI}=2$ ).

Layer II: TAR6-TP02-II-4-14*, 1dL fem, 1sR tt; TAR6-TP02-II-6-22-C, 1pR hum, 1L cor, 1pL tmt; TAR6-TP02-II-7-31-C, 1L scap, 1R quad; TAR6TP03-II-1-9A, 1dR tt; TAR6-TP05-II-1-19A*, 1R tt; TAR6-TP05-II-2-25A-E* ${ }^{*}$ 1L fem; TAR6-TP05-II-331A-C*, 1dR tt, 1pR tmt; TAR6-TP05-II-6-55A-C*, 1dL tt, 1pR tmt; TAR6-TP06-II-1-13A-D*, 1L fem; TAR6-TP06-II-1-13A-E* ${ }^{*}$ 1dL tt, 1R cor; TAR6TP06-II-2-19A-C*, 1pR fem, 1dL tt, 1dR ulna, 1R cor; TAR6-TP06-II-3-31A-B*, 1L cor, 1L fem, 1dR 1dL tt; TAR6-TP06-II-4-37A-E*, 1L cor, 1L scap; TAR6-TP11-II-2-9A-C* , 1L fem, 1R2L cor, 1L scap; TAR6-TP11-II-3-19A-F*, 1dL tt; TAR6-TP11-II-638A-E, 1dL fem; TAR6-TP11-II-8-St.2-51A-B*, 1pR hum; TAR6-TP12-II-5-32A-A, 1dL hum, 1L cor; TAR6-TP12-II-5-St.2-49A, $1 \mathrm{~L} \quad$ cor; $\quad(\mathrm{NISP}=38$; $\mathrm{MNI}=7$ ).

Layer II/III: TAR6-TP10-II/III-3-28A-C*, 2dL tt, pL tmt; (NISP=3; MNI=2).

Layer III: NMNZ S.47669 (=TAR6-TP02-III-833D*), 1 pmx, 1 pt cran, 1 ant stern, $1 \mathrm{dL}$ tt, 1R1pR1L cor, 1dL ulna, 1pL fem; NMNZ S.47670 (=TAR6-TP02-III-8-35D), 1R1sL1dL tt, 1R1L tmt, $1 \mathrm{R}$ cor, $1 \mathrm{R}$ quad, $1 \mathrm{sL}$ ulna, $1 \mathrm{pmx}, 1 \mathrm{R} 3 \mathrm{~L}$ art mand, 1R1L dent, 1L palatine; NMNZ S.47671 (=TAR6TP02-III-9-39G*), 1R3L cor, 1 ant stern, 2R2L scap, $1 \mathrm{~L}$ dent, 1 fur, 1 pt cran, $2 \mathrm{pmx}, 1 \mathrm{R} 1 \mathrm{~L} 1 \mathrm{dL} t \mathrm{tt}$, $3 \mathrm{~L}$ quad, $1 \mathrm{R}$ fem, 2dL1pL tmt; TAR6-TP02-III-1041, $1 \mathrm{R}$ quad, 1 pterygoid; TAR6-TP03-III-2-St.118A-A*, 1dR tt; TAR6-TP06-III-3-64A-C*, 1dR tt, $1 \mathrm{dR}$ tmt, 1pL fem; TAR6-TP10-III-4-29A-K, 1R cor, 1pL tt; TAR6-TP10-III-4-29A-B* , 1dR hum, 1R fem, 1R cor, 1pR2dL tmt, 1dR1dL tt; TAR6-TP10-III-429A-G*, 2dL tt; TAR6-TP10-III-4-29A-J*, 1dL tt; TAR6-TP10-III-5-35A-C*, 1dL tt; TAR6-TP10-III-535A-D, 1dR tt; TAR6-TP11-III-1-60A-A*, juv. 1L cor,
$1 \mathrm{dR}$ tt, 1pL fem; TAR6-TP11-III-2-65A-D*, 1L1pL rad; TAR6-TP11-III-2-65A-C, 1dL tmt; TAR6-TP11III-2-65A-Eb*, 1dR1dL tt; TAR6-TP11-III-2-65A$\mathrm{Fa}^{*}, 2 \mathrm{pR} 1 \mathrm{pL}$ tmt, 2pR fem, $5 \mathrm{dR}$ 3dL tt; TAR6TP11-III-2-65A-la*, 3R1pR1dR 2pL2dL fem; TAR6TP11-III-2-65A-Ja*, 1R 2dL tt, TAR6-TP11-III-265A-P*, 3L cor; TAR6-TP11-III-2-65A-R*, 2L cor; TAR6-TP11-III-2-65A-S*, 3R1L cor; TAR6-TP12-III9-55A-A, 1L cor; (NISP=113; $\mathrm{MNI}=15$ ).

Nenega-Iti Site (190-12-AGA-3), Agakauitai Is. (Total NISP=82; $\mathrm{MNI}=18$ ).

Layer III: AGA3-TP01-III-5-63, dL cmc; AGA3TP01-III-6-75, sL hum; AGA3-TP01-III-7-86A, 2pR1dL hum, L cmc; (NISP=8; $M N I=3)$.

Layer III/IV: AGA3-TP01-III/IV-interface-94A, pt pR tmt; (NISP=1; $M N I=1)$.

Layer IV/1: AGA3-D9-IV1-12-5-1A*, 1dL ulna; AGA3-D9-IV1-12-5-1B, 1dL cmc; AGA3-F9-IV1-95-54A, $1 \mathrm{dL} \mathrm{cmc}$; (NISP=3; $\mathrm{MNI}=2)$.

Layer IV/2: AGA3-E9-IV2-12-4-19A*, 1dL ulna; AGA3-E9-IV2-12-4-19B*, 1dL ulna; AGA3-F9-IV210-1-24A*, 1L cmc; NMNZ S.47672 (=AGA3-F9IV2-11-5-1A*), 1R cmc; AGA3-F9-IV2-11-5-1B, 1pR cmc; AGA3-F9-IV2-11-5-1C, 1R cmc; AGA3F9-IV2-11-5-1D, 1dL cmc; AGA3-F9-IV2-11-5-1F*, 1dR tmt; AGA3-F9-IV2-11-5-1G*, 1dR tmt; AGA3F9-IV2-11-5-1H, 1pL tmt; AGA3-F9-IV2-11-5-1I, 1L hum; AGA3-F9-IV2-11-5-1 J*, 1dR hum; AGA3-F9IV2-11-5-1K, 1dR hum; AGA3-F9-IV2-11-5-1M, 1R phal II.1; AGA3-F9-IV2-11-5-1N, 1 phal II.1; $(\mathrm{NISP}=15 ; \mathrm{MNI}=3)$.

Layer IV/3: AGA3-D9-IV3-18-5-12B*, 1dR hum; AGA3-D9-IV3-19-1-1A* , 1dR hum; NMNZ S.47673 (=AGA3-F9-IV3-12-8-1B*), 1dL hum; AGA3-F9IV3-12-8-1C*, 1dR hum; AGA3-F9-IV3-12-8-1D, $1 \mathrm{pL}$ hum; AGA3-F9-IV3-12-8-1E*, 1dR tmt; AGA3F9-IV3-12-8-1F, juv. 1dR tmt; AGA3-F9-IV3-12-81G, 1pL tmt; AGA3-F9-IV3-12-8-1J, 1dR cmc; AGA3-F9-IV3-12-8-1K, 1dR cmc; AGA3-F9-IV312-8-1N*, 1dR ulna; AGA3-F9-IV3-12-8-1P*, 1pR ulna; AGA3-F9-IV3-12-8-1Q, 1pR rad; AGA3-F9IV3-12-8-1R, $1 \mathrm{pL}$ rad; AGA3-G9-IV3-12-1-1A*, 1dR tmt; AGA3-G9-IV3-12-1-1B* 1 dR ulna; AGA3G9-IV3-12-1-1C*, 1pL ulna; AGA3-G9-IV3-12-11E*, 1L cmc; AGA3-G9-IV3-12-1-1G*, 1dR hum; AGA3-G9-IV3-12-1-1I, $1 \mathrm{pL}$ hum; $\quad(\mathrm{NISP}=20$; $\mathrm{MNI}=4)$.

Layer IV/4: AGA3-D9-IV4-20-5-1B*, $1 \mathrm{~L} \mathrm{tmt;} \mathrm{AGA3-}$ D9-IV4-20-5-1D*, 1dL tt; AGA3-D9-IV4-20-5-1E, 1L ulna; AGA3-D9-IV4-20-5-1F*, 1pR ulna; AGA3D9-IV4-21-5-1B*, 1dL hum; AGA3-D9-IV4-21-51D*, 1dL tt; NMNZ S.47674 (=AGA3-D9-IV4-21-5$1 \mathrm{E}^{*}$ ), 1pR cmc; NMNZ S.47675 (=AGA3-D9-IV421-5-1H*), 1R ulna; AGA3-D9-IV4-21-5-1 $\mathrm{J}^{*}, 1 \mathrm{dR}$ 
ulna; AGA3-D9-IV4-21-5-1P, 1pR hum; AGA3-E9IV4-14-4-1A*, 1dR hum; AGA3-E9-IV4-14-4-1C, $1 \mathrm{pL}$ cmc; AGA3-F9-IV4-13-1-1A*, 1dL hum; NMNZ S.47676 (=AGA3-F9-IV4-13-1-1B*), 1dR hum; AGA3-F9-IV4-13-1-1C, 1pL hum; AGA3-F9-IV413-1-1D, 1pR hum; NMNZ S.47677 (=AGA3-F9IV4-13-1-1E*), 1pL hum; AGA3-F9-IV4-13-1-1F, 1L phal II.1; AGA3-F9-IV4-13-1-1G*, 1dL cmc; AGA3F9-IV4-13-1-1H, 1pL cmc; AGA3-F9-IV4-13-1-1 J*, 1R ulna; AGA3-F9-IV4-13-1-1K*, $1 \mathrm{~L}$ ulna; AGA3F9-IV4-13-1-1O, 1pL rad; AGA3-F9-IV4-13-1-1P, 1dR rad; AGA3-F9-IV4-13-3-1B*, 1R hum; AGA3F9-IV4-13-3-1C*, $1 \mathrm{~L} \mathrm{tmt;} \mathrm{AGA3-F9-IV4-13-3-1D*,}$ 1pL ulna; AGA3-F9-IV4-13-3-1E*, 1dL ulna; AGA3F9-IV4-13-6-1A*, 1R tmt; AGA3-F9-IV4-13-6-1D*, 1dL tt; AGA3-F9-IV4-13-6-1J, 1dL cmc; AGA3-F9IV4-13-6-1K, 1dL cmc; AGA3-G9-IV4-13-1-1B*, $1 \mathrm{dR}$ ulna; $\mathrm{NISP}=33 ; \mathrm{MNI}=4)$.

Layer IV/5: AGA3-F9-IV/V-14-1-1A*, 1dL hum; AGA3-F9-IV/V-14-1-1B*,$\quad 1 \mathrm{dL}$ ulna; $\quad(\mathrm{NISP}=2$; $\mathrm{MNI}=1)$.

\section{Measurements}

Summary statistics for measurements $(\mathrm{mm})$ of the Pseudobulweria bones are compared to those of individuals of other procellariids in Table 1.

Skull Measurements. Anterior cranial fragment (NMNZ S.47669): preorbital width (estimated from the complete right side) is $19.0 \mathrm{~mm}$; nasofrontal hinge width, $\sim 9.4 \mathrm{~mm}$, is $52 \%$ of preorbital width. Premaxilla (NMNZ S.47669): TL $\sim 30.0 \mathrm{~mm}$; hinge to nares $\sim 4.4 \mathrm{~mm}$; length nares $7.5 \mathrm{~mm}$; length from anterior nares to tip $18.0 \mathrm{~mm}$; depth at cranial end of nares $8.0 \mathrm{~mm}$. Premaxilla (NMNZ S.47670): $\mathrm{TL} \sim 31.5 \mathrm{~mm}$; length nares $10.5 \mathrm{~mm}$; length from anterior nares to tip $18.1 \mathrm{~mm}$; depth at cranial end of nares $9.1 \mathrm{~mm}$. Premaxilla (NMNZ S.47671): TL $\sim 30.9 \mathrm{~mm}$; length nares $8.0 \mathrm{~mm}$; length from anterior nares to tip $18.5 \mathrm{~mm}$; depth at cranial end of nares $8.3 \mathrm{~mm}$.

\section{Comments}

The abundant bones listed here represent a small species of Pseudobulweria, one that is slightly smaller than Pterodroma heraldica or similar to $P$. leucoptera. This taxon was first identified by Worthy and Tennyson (2004) and is much smaller than $P$. rostrata, precluding their being small specimens of that taxon (contra Thibault and Cibois, 2017). In terms of proportions, this Gambier species of Pseudobulweria compares to the similar-sized and sympatric Pterodroma leucoptera (SAM B31271a) as follows: the premaxilla is of similar length; the coracoids are slightly smaller overall; the ulnae and humeri are slenderer, but slightly longer; the tibiotarsi are slightly longer, but stouter, especially distally; and the tarsometatarsi are slenderer and longer.

The Gambier taxon conforms with Pseudobulweria rostrata and differs from species of Pterodroma as follows. Cranium: relatively narrower in dorsal view at both lacrymals and processus postorbitales, but with a relatively wider nasofrontal hinge; the preorbital region at the lacrymals is craniocaudally shorter and the preorbital lacrymal processes more directed caudally; the fossae temporales are more extensive both craniocaudally and medially, meeting on the midline; the nares are more widely separated from the nasofrontal hinge on the premaxilla at a distance of about $2 / 3$ hinge width ( $1 / 2$ in Pterodroma); and the processus nasalis of the premaxilla is not evident at or anterior to hinge (lateral edges well-marked by lines in Pterodroma). Humerus: more elongate and the impression for the brachialis anticus within the fossa brachialis is well defined distally and near circular (not defined well distally and oval in Pterodroma). Ulna: more elongate and the tip of the tuberculum carpale projects somewhat distally enclosing a notch distally (markedly so in $P$. rostrata; projects somewhat proximally in Pterodroma). Carpometacarpus: the processus pisiformis is much larger. Coracoid: the processus acrocoracoideus is much deeper dorsoventrally and depth widens towards the tip, whereas depth at along the processus is similar in Pterodroma. Tarsometatarsus: much more elongate relative to both humeri and coracoids and more strongly ridged dorsally, especially along the lateral side enclosing a much deeper sulcus extensorius. Lastly, Pseudobulweria has a major structural difference of the hypotarsus, where the middle hypotarsal ridge (crista lateralis flexoris digitorum longus, Mayr, 2016), which is prominent in Pterodroma, is markedly reduced. This results in the lateral sulcus for the tendon of musculus flexor hallucis longus (fhl) being merged with that medially for the sulcus for the tendon of musculus flexor digitorum longus (fdl) as a single sulcus. Bounding this laterally, the crista lateralis flexoris hallucis longus is much more robust and, plantarly, is both laterally and medially expanded to form a broad, flat, crista with a shallow sulcus for the tendon of musculus flexor perforatus digiti 2 on its plantar side.

Three species of Pseudobulweria occur in the Pacific, Tahiti Petrel P. rostrata, Beck's Petrel $P$. becki, and Fiji Petrel P. macgillivrayi, one in the Indian Ocean Mascarene Petrel $P$. aterrima and an 
TABLE 1. Measurements $(\mathrm{mm})$ of exemplary specimens of extant taxa PSRO (Pseudobulweria rostrata, NMNZ 0.24691), PTLE (Pterodroma leucoptera SAM B31271a), and PTHE (Pterodroma heraldica NMNZ 0.24691) compared to summary statistics of specimens (see *) listed as Pseudobulweria sp. indet. from two Gambier Group sites (Onemea and Nenega-lti). Abbreviations: TL, total length, except for tibiotarsi, where length is from the proximal articular surface; PW, proximal width; DW, distal width; MDWS, tibiotarsus distal minimum width shaft; Mdws, tibiotarsus craniocaudal depth shaft at minimum width point; Am-a, angulus medialis to acrocoracoideus; Am-cs, angulus medialis to cotyla scapularis; Cs-a, cotyla scapularis to acrocoracoideus; Cs-fah, cotyla scapularis to facies articularis humeralis; MSW, humerus mid-shaft dorsoventral width; Msw, humerus mid-shaft craniocaudal depth; DCW, distal condylus width.

\begin{tabular}{|c|c|c|c|c|c|c|c|c|c|c|c|c|c|}
\hline & \multicolumn{3}{|c|}{ Femur } & \multicolumn{4}{|c|}{ Tibiotarsus } & \multicolumn{3}{|c|}{ Tarsometatarsus } & \multirow{2}{*}{$\begin{array}{c}\text { Scapula } \\
\text { PW }\end{array}$} & \multicolumn{2}{|c|}{ Carpometacarpus } \\
\hline & TL & PW & DW & TL & DW & MDWS & Mdws & TL & PW & DW & & TL & PW \\
\hline PSRO & - & 7.5 & - & - & 6.4 & 3.6 & - & 49.1 & 7.7 & 7.3 & - & 51.8 & 10.6 \\
\hline PTLE & 26.6 & 4.9 & 4.4 & 51.8 & 4.1 & 2.0 & 1.8 & 29.8 & 5.0 & 4.7 & 6.8 & 35.3 & 8.6 \\
\hline PTHE & 29.7 & 5.9 & 5.3 & 53.5 & 5.0 & 2.7 & - & 33.6 & 6.0 & 5.8 & - & 43.3 & 10.3 \\
\hline Mean & 25.5 & 5.2 & 4.8 & 51.6 & 4.6 & 2.6 & 1.9 & 36.1 & 5.5 & 5.2 & 6.4 & 38.0 & 8.4 \\
\hline Min & 24.0 & 4.9 & 4.5 & 50.5 & 4.2 & 2.4 & 1.6 & 35.6 & 5.1 & 4.8 & 5.7 & 37.4 & 8.3 \\
\hline Max & 26.2 & 6.1 & 5.1 & 52.7 & 5.0 & 2.9 & 2.2 & 36.7 & 5.7 & 5.5 & 6.8 & 38.7 & 8.4 \\
\hline Std dev & 0.70 & 0.27 & 0.27 & 1.00 & 0.17 & 0.14 & 0.13 & 0.57 & 0.19 & 0.22 & 0.52 & 0.63 & 0.06 \\
\hline Count & 8 & 17 & 9 & 4 & 42 & 30 & 30 & 3 & 9 & 14 & 4 & 3 & 2 \\
\hline
\end{tabular}

\begin{tabular}{|c|c|c|c|c|c|c|c|c|c|c|c|c|c|c|}
\hline & \multicolumn{4}{|c|}{ Coracoid } & \multicolumn{4}{|c|}{ Humerus } & \multicolumn{4}{|c|}{ UIna } & \multicolumn{2}{|c|}{ Radius } \\
\hline & Am-a & Am-cs & Cs-a & Cs-fah & PW & DW & MSW & Msw & TL & PW & DW & DCW & TL & DW \\
\hline PSRO & 27.3 & - & - & - & 15.3 & 11.7 & 5.1 & - & 108.6 & 7.7 & 7.7 & - & - & - \\
\hline PTLE & 21.5 & 17.0 & 8.4 & 5.7 & 11.0 & 8.5 & 4.1 & 3.2 & 71.5 & 6.5 & 5.1 & 4.8 & 69.0 & 4.9 \\
\hline PTHE & 23.2 & - & - & - & 13.8 & 10.6 & 4.6 & - & 92.0 & 7.2 & 7.7 & - & - & - \\
\hline Mean & 19.5 & 14.7 & 8.4 & 5.5 & 11.0 & 8.8 & 4.0 & 3.0 & 81.6 & 6.9 & 5.8 & 4.1 & 79.9 & 4.1 \\
\hline Min & 18.4 & 13.5 & 7.9 & 5.1 & 10.9 & 7.5 & 3.8 & 2.4 & 80.0 & 5.7 & 5.2 & 3.2 & - & - \\
\hline Max & 21.2 & 16.0 & 9.2 & 6.0 & 11.1 & 9.2 & 4.1 & 3.2 & 83.1 & 7.4 & 6.8 & 4.9 & - & - \\
\hline Std dev & 0.79 & 0.63 & 0.39 & 0.26 & 0.11 & 0.50 & 0.11 & 0.23 & 2.16 & 0.61 & 0.40 & 0.36 & - & - \\
\hline Count & 18 & 18 & 18 & 18 & 3 & 9 & 11 & 11 & 2 & 7 & 14 & 14 & 1 & 1 \\
\hline
\end{tabular}

extinct taxon $P$. rupinarum is known from St Helena Island in the Atlantic Ocean (see Gangloff et al., 2012; Dickinson and Remsen, 2013). The bones recorded here represent a much smaller species than $P$. rostrata (culmen length $33.1-38.2 \mathrm{~mm}$, tarsus length 43.3-51.0 mm; Villard et al., 2006), which is the only extant representative of this genus known from the Gambier Group (Thibault and Cibois, 2017). Based on a tarsometatarsus length of $35.6-36.7 \mathrm{~mm}$ (Table 1) and a premaxilla length c. $30.0 \mathrm{~mm}$ (NMNZ S.47669) the species formerly in the Gambier Group was of similar size to the remaining three extant species of Pseudobulweria. Of the Pacific taxa, P. macgillivrayi breeding on Gau Island, Fiji (Watling and Lewanavanua, 1985; Priddel et al., 2008; Shirihai et al., 2009), is geographically the closest breeding species, and is of appropriate size with a tarsus length of 36-38 $\mathrm{mm}$ and an unfeathered bill length (slightly less than premaxilla length) of $25.0-25.7 \mathrm{~mm}$ (Shirihai et al., 2009).

Steadman and Justice (1998) identified an ulna $78 \mathrm{~mm}$ long as Bulweria sp. cf. B. fallax, however this bone was not compared to those of any species of Pseudobulweria. Among the ulnae, we attribute to Pseudobulweria sp. are two with complete length $(80,83 \mathrm{~mm}$; Table 1$)$, which are not the smallest in the sample, so the bone attributed to Bulweria could be the same taxon, as suggested by Worthy and Tennyson (2004). This suggestion is supported by the observation that the ulnae we refer to Pseudobulweria have the main features used by Steadman and Justice (1998) to typify Bulweria (slender shaft and small olecranon). It is not clear to us what Steadman and Justice (1998: table 4) meant by the character "Junction of processus cotylaris dorsalis with shaft in dorsal aspect" identified as intermediate, compared to abrupt in Puffinus and gradual in Pterodroma. However, the 
processus cotylaris dorsalis is smaller/less projecting in the ulnae identified as Pseudobulweria sp. than in species of Puffinus, but it is similar in size and projection to, for example, Pterodroma leucoptera, and in all compared taxa, the distal margin of the processus is at right angles to the shaft in dorsal view.

Genus PTERODROMA Bonaparte, 1856 Pterodroma magn. P. heraldica (Salvin, 1888), Herald Petrel

\section{Material}

Onemea Site (190-12-TAR-6), Taravai Is. (Total $\mathrm{NISP}=55 ; \mathrm{MNI}=8$ ).

Layer II: TAR6-TP02-II-3-8, 1pR hum; TAR6-TP05II-1-15A-B, 1L tmt; TAR6-TP05-II-1-15A-D, 1R cor; TAR6-TP05-II-2-25A-A, $1 \mathrm{~L} \mathrm{cmc,} \mathrm{1R} \mathrm{cor;} \mathrm{TAR6-}$ TP05-II-3-31A-D, 1dR rad; TAR6-TP05-II-3-31A-F, 1L scap; TAR6-TP05-II-4-39A-C, 1R cor; TAR6TP05-II-4-39A-D, 1L scap; TAR6-TP05-II-5-45A-B, 1R scap; TAR6-TP05-II-6-55A-I, 1L cor; TAR6TP05-II-6-55A-J, 1L cor, 1R scap; TAR6-TP06-II-113A-C, 1R1pL fem; TAR6-TP06-II-1-13A-H, 1pR rad; TAR6-TP06-II-1-13A-J, 1dL hum, 1R scap; TAR6-TP06-II-3-31A-C, 1L cor, 1pR tmt; TAR6TP06-II-5-Fosse-46A-C, 1dR tt; TAR6-TP11-II-16A-A, 1dL hum; TAR6-TP11-II-1-6A-B, 1pL tmt; TAR6-TP11-II-2-9A-A, 1 synsacrum, 1R phal II.1, 1R cmc, 1L cor; TAR6-TP11-II-2-9A-Bb, 1dR hum; TAR6-TP11-II-3-19A-E, 1pR hum; TAR6-TP12-II-5St.1-27A-B, 1dR1dL tmt, 1R scap; $(\mathrm{NISP}=32$; $\mathrm{MNI}=4)$.

Layer III: TAR6-TP02-III-9-39F, 2R1L cor, 1 ant stern, 1dR fem; TAR6-TP10-III-4-29A-I, 1dR tt; TAR6-TP10-III-4-29A-L, 1pR tt; TAR6-TP11-III-265A-Bc, 1dR tt; TAR6-TP11-III-2-65A-Fb, 1dR tmt, 1R scap, 1pR ulna; TAR6-TP11-III-2-65A-H, 1R fem; TAR6-TP11-III-2-65A-lb, 1pR fem; TAR6TP11-III-2-65A-Jb, 1dR tt; TAR6-TP11-III-2-65AOb, 2R cor, 1dL tmt; TAR6-TP11-III-2-65A-Q, 3L cor; (NISP=20; $\mathrm{MNI}=4)$.

Unknown (Layer X): TAR6-TP10-X-St.1-34A-B, 1dL tt; TAR6-TP10-X-St.1-34A-D, 1dL tmt, 1pR fem; (NISP=3; MNI=1).

Nenega-Iti Site (190-12-AGA-3), Agakauitai Is. (Total NISP=6; $\mathrm{MNI}=3$ ).

Layer IV: AGA3-F9-IV2-11-5-1E, 1dR tmt; AGA3D9-IV3-18-5-12A, 1pR tmt; AGA3-F9-IV3-12-8-1O, 1dR cmc; AGA3-F9-IV3-12-8-1S, 1dL rad; AGA3D9-IV4-21-5-1I, 1pL rad; AGA3-G9-IV4-13-1-1C, $1 \mathrm{pR}$ ulna; (NISP=6; MNI=3).

Kitchen Cave (190-04-KAM-1), Kamaka Is. (Total $\mathrm{NISP}=4 ; \mathrm{MNI}=1)$.
Layer V: KAM1-C3-V-14-3-23C, 1sR hum; KAM1B2-V-Fe10-1-1, 1L ulna; (NISP=2; $\mathrm{MNI}=1$ ).

Layer VI: KAM1-B3TP1-VI-17-1A-B, 1pL tmt; KAM1-B3TP1-VI-17-1A-C, 1dL hum; (NISP=2; $\mathrm{MNI}=1$ ).

As described above in 'Nomenclature', we list under this taxon bones of the medium-sized species of Pterodroma. The bones are similar in size to those of our individual reference specimen of $P$. heraldica given in Table 1 and larger than those listed under our small size-class taxon below. However, as detailed above, these are likely to mainly include three taxa with widely overlapping size known to breed in the Gambier Group (Herald Petrel $P$. heraldica, Murphy's Petrel $P$. ultima, and the Kermadec Petrel P. neglecta), although bones of vagrant individuals of further similar-sized taxa, such as Phoenix Petrel $P$. alba and Henderson Petrel $P$. atrata could also be present as well (Thibault and Cibois, 2017). It is not considered feasible to distinguish any of these taxa on the basis of the morphology of postcranial remains (Murphy and Pennoyer, 1952; Marchant and Higgins, 1990; Walker et al., 1990; Wragg, 1995; Cooper and Tennyson, 2008; Tennyson et al., 2015).

Pterodroma magn. P. leucoptera (Gould, 1844) White-winged Petrel

\section{Material}

Onemea Site (190-12-TAR-6), Taravai Is. (Total $\mathrm{NISP}=22 ; \mathrm{MNI}=5$ ).

Layer I: TAR6-TP05-I-2-6A-A, 1R scap; (NISP=1; $\mathrm{MNI}=1$ ).

Layer II: TAR6-TP05-II-3-31A-E, 1R scap; TAR6TP06-II-1-13A-I, 1R scap; TAR6-TP11-II-3-19A-B, 1 synsacrum, 1dR tt; TAR6-TP11-II-6-38A-C, 1dR $\mathrm{tt} ;(\mathrm{NISP}=5 ; \mathrm{MNI}=2)$.

Layer III: TAR6-TP10-III-4-29A-D, $1 \mathrm{~L}$ quad, 1L fem, 1pR tmt, 1dR1dL tt; TAR6-TP10-III-5-35A-B, juv 1pL fem; TAR6-TP11-III-2-65A-Ea, 1dR hum, 1pR fem, 2R1L quad, 1R1L scap; TAR6-TP11-III-2-65AOa, 2L cor; TAR6-TP12-III-9-55A-B; 1L scap; (NISP=16; MNI=2).

Under this taxon, we list remains of Pterodroma, which derive from smaller species than that in the previous size-class taxon. The bones are similar in size to those of an individual $P$. leucoptera given in Table 1. However, see Cooper and Tennyson (2008, appendix 1.2) for data showing how metrics for a large sample of a similar-sized common species (P. nigripennis) far exceed those in the small $(n=2)$ sample for the rare taxon $(P$. leucoptera), whose size range would in reality be expected to approach that of the former species. In 
the eastern Pacific region, such small species of Pterodroma potentially include either formerly breeding and or seasonally visiting Gould's Petrel Pterodroma leucoptera, Collared Petrel P. brevipes, Pycroft's Petrel P. pycrofti and Black-winged Petrel $P$. nigripennis (Dickinson and Remsen, 2013; Rayner et al., 2016; BirdLife International, 2017). Skeletal measurements for all except $P$. brevipes are given by Cooper and Tennyson (2008). Pterodroma brevipes, which mainly breeds in the Vanuatu - Fiji region, has a small breeding population on Raivavae, Austral Islands, and currently forages near the Gambier Group. In 1922, a mummified wing (AMNH 191743) was collected on Mangareva, which may reflect a lost breeding population (Thibault and Cibois, 2012, 2017). As for the previous taxon, these species all have broadly overlapping size and their discrimination based on morphology of post cranial bones is not considered feasible (Murphy and Pennoyer, 1952; Marchant and Higgins, 1990; Walker et al., 1990; Wragg, 1995; Cooper and Tennyson, 2008; Tennyson et al., 2015).

\section{Pterodroma sp. indet.}

\section{Material}

Onemea Site (190-12-TAR-6), Taravai Is. (Total $\mathrm{NISP}=7 ; \mathrm{MNI}=3$ ).

Layer II: TAR6-TP05-II-6-55A-G, 1L scap; TAR6TP06-II-2-19A-B, 1R1L fem, 1dR tt, 1R cor; TAR6TP11-II-6-38A-D, 2pL fem; (NISP=7; MNI=3).

Nenega-Iti Site (190-12-AGA-3), Agakauitai Is. (Total NISP $=1 ; \mathrm{MNI}=1$ ).

Layer II: AGA3-D12-II2-3-6-27, 1dR tt; (NISP=1; $\mathrm{MNI}=1)$.

Kitchen Cave (190-04-KAM-1), Kamaka Is. (Total $\mathrm{NISP}=1 ; \mathrm{MNI}=1$ ).

Layer III: KAM1-C3-III1-3-11-45A, 1dL rad; $(\mathrm{NISP}=1 ; \mathrm{MNI}=1)$.

These bones are not well-enough preserved to be specifically identifiable, but may from the above species of Pterodroma.

Genus PUFFINUS Brisson, 1760

Puffinus magn. P. bailloni Bonaparte, 1857, Tropical Shearwater

\section{Material}

Onemea Site (190-12-TAR-6), Taravai Is. (Total $\mathrm{NISP}=26 ; \mathrm{MNI}=8$ ).

Layer I: TAR6-TP11-I-1-3A-A, 1R articular pt mand; $(\mathrm{NISP}=1 ; \mathrm{MNI}=1)$.

Layer II: TAR6-TP05-II-1-15A-E, 1dR tt; TAR6TP05-II-2-25A-F*, 1dL rad, TAR6-TP05-II-4-39A-B,
1dR tt; TAR6-TP05-II-5-45A-C, $1 \mathrm{~L}$ cor; TAR6TP05-II-6-55A-E*, 1sL tmt, 1R scap, 1dR tt; TAR6TP11-II-2-9A-Ba*, 1dR1dL tt; TAR6-TP11-II-3-19A$\mathrm{D}, 1 \mathrm{pR}$ fem $1 \mathrm{R}$ cor; (NISP=11; $\mathrm{MNI}=4)$.

Layer III: TAR6-TP10-III-4-29A-F*, 1R2L scap; TAR6-TP11-III-2-65A-Ba*, 1R fem, 1L scap, 2pR tmt, 1pR hum, 2dR1dL tt, 1R cor; TAR6-TP12-III-747A-A*, pt 1L fibula, $1 \mathrm{~L} \mathrm{tt}$; (NISP=14; $M N I=3)$.

Nenega-Iti Site (190-12-AGA-3), Agakauitai Is. (Total NISP=6; $\mathrm{MNI}=4$ ).

Layer II: AGA3-D9-II2-5-4-18*, 1dL hum; AGA3E9-II2-5-7-72A*, 1dL ulna; AGA3-E9-II2-5-7-72B*, $1 \mathrm{dR}$ tt; AGA3-E9-II3-6-1-25A*, 1dL tt; $\quad(\mathrm{NISP}=4$; $\mathrm{MNI}=2$; treating II2 and II3 separately).

Layer III: AGA3-F9-III-7-3-18A, 1dL tt; (NISP=1; $\mathrm{MNI}=1$ ).

Layer IV: AGA3-F9-IV4-13-6-1H*, $1 \mathrm{dR}$ rad; $(\mathrm{NISP}=1 ; \mathrm{MNI}=1)$.

Kitchen Cave (190-04-KAM-1), Kamaka Is. (Total $\mathrm{NISP}=11 ; \mathrm{MNI}=6$ ).

Layer I: KAM1-C4-I-1-2-13A, 1pL hum; (NISP=1; $\mathrm{MNI}=1$ ).

Layer II: KAM1-B2-II-2-1-31B*, 1dL tt, 1pR hum; $(\mathrm{NISP}=2 ; \mathrm{MNI}=1)$.

Layer III: KAM1-B3TP1-III2-5-5AO-A, 1dR rad; KAM1-B3TP1-III2-7-5A-C*, 1pL hum; KAM1-B4III2-6-6-45B, 1dR tmt; (NISP=3; MNI=1).

Layer IV: KAM1-B2-IV1-7-1-23B*, 1dL fem; KAM1B2-IV1-8-2-1, 1pL tt; KAM1-C3-IV1-10-4-45B, 1R cor; KAM1-B4-IV2-12-3-38B, $1 \mathrm{~L}$ cor; $\quad(\mathrm{NISP}=4$; $\mathrm{MNI}=2$ ).

Layer V: KAM1-C4-V-14-8-15A*, 1dL tt; (NISP=1; $\mathrm{MNI}=1$ ).

As noted above, specimens listed here under the taxon Puffinus magn. P. bailloni include small (Table 2) Puffinus bones, which based on the current breeding distributions of taxa are probably mainly of $P$. bailloni. The taxon $P$. bailloni includes forms from Eastern Polynesia previously listed as Little Shearwater $P$. assimilis or Audubon's Shearwater $P$. Iherminieri. But, as noted in the Introduction under nomenclature, other similar-sized species that probably forage in the region may be included in the sample as follows: Puffinus bailloni gunax (breeding Vanuatu), $P$. auricularis myrtae (=P. newelli myrtae in del Hoyo et al. (2017) and Puffinus assimilis kermadecensis; see Marchant and Higgins (1990) and Pyle et al. (2011) for metrics on specimens from extant populations of these taxa. Puffinus bailloni currently breeds mainly on Manui and Motu Teiku, but also does so on Mangareva, Makaroa, Akamaru, and Kamaka (Thibault and Cibois, 2017). 
TABLE 2. Summary statistics ( $X$, mean; Min minimum; Max maximum; $n$ count) of measurements (mm) of bones listed as Puffinus magn. P. bailloni from three sites in the Gambier Group (Onemea TAR-6, Nenega-Iti AGA-3 and Kitchen Cave KAM-1). Gambier specimens used: see * in specimen list in Systematics section; gavia is P. gavia SAM B.55367; assimilis is $P$. assimilis kermadecensis (NMNZ O.23972, 24230, 24229, 15912, 23986, 24229, 24381, 24382, 15911). Standard length measurements are presented for $P$. assimilis kermadecensis to show how much smaller this taxon is than the $P$. gavia specimen used to identify the Gambier bones to genus. As discussed under nomenclature, the Gambier size-based taxon used here could include Puffinus bailloni dichrous, $P$. bailloni gunax, $P$. auricularis myrtae and $P$. assimilis kermadecensis, which all have broadly overlapping size distributions (Marchant and Higgins, 1990; Pyle et al., 2011). However, our data presented here for $P$. assimilis kermadecensis suggest it is a smaller bird than the Gambier birds were. Abbreviations: TL, Total length; PW, proximal width; DW, distal width; TSW, tibiotarsus minimal shaft width; $\mathrm{ML}$, angulus medialis to processus acrocoracoideus; M-cs, angulus medialis to cotyla scapularis; Cs-a, cotyla scapularis to processus acrocoracoideus.

\begin{tabular}{|c|c|c|c|c|c|c|c|c|c|c|c|c|c|c|c|c|c|}
\hline & & $\begin{array}{c}\text { Fem } \\
\text { TL }\end{array}$ & $\begin{array}{l}\text { Fem } \\
\text { PW }\end{array}$ & $\begin{array}{l}\text { Fem } \\
\text { DW }\end{array}$ & $\begin{array}{l}\text { Tib } \\
\text { artL }\end{array}$ & $\begin{array}{l}\text { Tib } \\
\text { DW }\end{array}$ & $\begin{array}{l}\text { Tib } \\
\text { sw }\end{array}$ & $\begin{array}{l}\text { Cor } \\
\text { ML }\end{array}$ & $\begin{array}{l}\text { Cor } \\
\text { M-cs }\end{array}$ & $\begin{array}{l}\text { Cor } \\
\text { Cs-a }\end{array}$ & $\begin{array}{c}\text { Hum } \\
\text { L }\end{array}$ & $\begin{array}{c}\text { Hum } \\
\text { PW }\end{array}$ & $\begin{array}{l}\text { Hum } \\
\text { DW }\end{array}$ & $\begin{array}{c}\text { Ulna } \\
\text { L }\end{array}$ & $\begin{array}{l}\text { Ulna } \\
\text { DW }\end{array}$ & $\begin{array}{c}\text { Cmc } \\
\mathrm{L}\end{array}$ & $\begin{array}{l}\text { Rad } \\
\text { DW }\end{array}$ \\
\hline \multirow[t]{5}{*}{ Gambier } & $x$ & 29.8 & 6.7 & 5.7 & & 5.3 & 3.3 & 25.9 & 19.1 & 11.6 & & 10.4 & 9 & & 5.6 & & 4.7 \\
\hline & Min & & & 5.1 & & 4.2 & 3 & & & & & 10.3 & & & & & \\
\hline & Max & & & 6.2 & & 6.5 & 3.5 & & & & & 10.6 & & & & & \\
\hline & SD & & & & & 0.69 & 0.2 & & & & & & & & & & \\
\hline & $\mathrm{n}$ & 1 & 1 & 2 & & 11 & 9 & 1 & 1 & 1 & & 2 & 1 & & 1 & & 1 \\
\hline gavia & & 30.5 & 7.2 & 6.6 & 63.6 & 5.6 & 3.4 & 28 & 19.8 & 12.5 & 73.5 & 14.1 & 10.3 & 64.4 & 6.7 & 38.1 & 5.1 \\
\hline \multirow[t]{5}{*}{ assimilis } & $x$ & 24.0 & & & 53.8 & & & 21.1 & & & 59.7 & & & 51.8 & & 31.9 & \\
\hline & Min & 23.1 & & & 51.9 & & & 20.0 & & & 57.0 & & & 51.8 & & 30.7 & \\
\hline & Max & 25.0 & & & 56.8 & & & 22.6 & & & 62.9 & & & 51.8 & & 33.4 & \\
\hline & SD & 0.60 & & & 1.77 & & & 0.92 & & & 1.86 & & & 51.8 & & 1.00 & \\
\hline & $\mathrm{n}$ & 9 & & & 9 & & & 9 & & & 9 & & & 51.8 & & 9 & \\
\hline
\end{tabular}

Puffinus nativitatis Streets, 1877, Christmas Shearwater

\section{Material}

Onemea Site (190-12-TAR-6), Taravai Is. (Total $\mathrm{NISP}=28 ; \mathrm{MNI}=5$ ).

Layer II: TAR6-TP05-II-2-25A-D, 1pL tmt; TAR6TP06-II-1-13A-F, 1dR tt, 1pL1dL tmt; TAR6-TP06II-4-37A-D, 1dL rad; (NISP=5; MNI=2).

Layer III: TAR6-TP02-III-8-33-C, 1L cor, 1sL tt, 1R scap; TAR6-TP02-III-8-35-C, 1sR tt, 1R tmt, 1 ant stern, 1R quad; TAR6-TP02-III-9-39-C, 2R1L cor, 1R2L scap, 2 ant stern, 1R tmt, 1dR tt, 1R1sL fem; TAR6-TP06-III-3-64A-A, 1R tmt, 1pR hum, 1R scap; TAR6-TP11-III-2-65A-Bb, $1 \mathrm{dR}$ hum; $(\mathrm{NISP}=23 ; \mathrm{MNI}=3$ ).

Nenega-Iti Site (190-12-AGA-3), Agakauitai Is. (Total NISP=9; $\mathrm{MNI}=3$ ).

Layer IV: AGA3-F9-IV2-10-1-24B, 1R cmc; AGA3D9-IV4-20-5-1C, 1dL tmt; AGA3-D9-IV4-21-5-1A, 1pL hum; AGA3-D9-IV4-21-5-1F, 1pL cmc; AGA3E9-IV4-14-4-1B, 1dR cmc; AGA3-F9-IV4-13-6-1B, 1dL tmt; AGA3-F9-IV4-13-6-1C, 1dR tt; AGA3-F9IV4-13-6-1I, 1dR rad; AGA3-G9-IV4-13-1-1A, 1pL cor; (NISP=9; $\mathrm{MNI}=3$, allowing sub-layers).

Kitchen Cave (190-04-KAM-1), Kamaka Is. (Total $\mathrm{NISP}=1 ; \mathrm{MNI}=1)$.
Layer IV: KAM1-C4-IV1-11-3-62B, 1dR tt; (NISP=1; $\mathrm{MNI}=1$ ).

The Christmas Shearwater $P$. nativitatis has a widespread breeding distribution in Eastern Polynesia, including in the Gambier Group (Thibault and Cibois, 2017).

Puffinus sp. Indet.

\section{Material}

Nenega-Iti Site (190-12-AGA-3), Agakauitai Is. (Total NISP $=1 ; \mathrm{MNI}=1$ ).

Layer IV: AGA3-D9-IV3-19-1-B, 1pL tmt; (NISP=1; $\mathrm{MNI}=1)$.

Genus ARDENNA Reichenbach, 1853

Ardenna pacifica (Gmelin, 1789), Wedge-tailed Shearwater

\section{Material}

Onemea Site (190-12-TAR-6), Taravai Is. (Total $\mathrm{NISP}=12 ; \mathrm{MNI}=4$ ).

Layer I: TAR6-TP05-I-1-1A-B, 1pR hum; (NISP=1; $\mathrm{MNI}=1$ ).

Layer II: TAR6-TP06-II-1-13A-G, 1R phal II.1; TAR6-TP11-II-3-19A-G, 1pR hum; TAR6-TP11-II-423A-B, 1dR ulna; (NISP=3; MNI=1). 
Layer III: TAR6-TP02-III-9-39-D, 1R tmt, 1dR tt; TAR6-TP02-III-9-39-E, 1R1L scap, 1pR fem; TAR6-TP11-III-2-65A-C, 1pR hum; TAR6-TP11-III2-65A-Ec, 1L scap; TAR6-TP11-III-2-65A-K, 1dL tt; $(\mathrm{NISP}=8 ; \mathrm{MNI}=2)$.

Nenega-lti Site (190-12-AGA-3), Agakauitai Is. (Total NISP=3; $\mathrm{MNI}=1$ ).

Layer IV: AGA3-F9-IV3-12-8-1I, dR cmc; AGA3F9-IV3-12-8-1L, dR ulna; AGA3-G9-IV3-12-1-1H, pL hum; (NISP=3; MNI=1).

Kitchen Cave (190-04-KAM-1), Kamaka Is. (Total $\mathrm{NISP}=2 ; \mathrm{MNI}=2$ ).

Layer IV: KAM1-B3TP1-IV2-12-1A-A, 1pL ulna; $(\mathrm{NISP}=1 ; \mathrm{MNI}=1)$.

Layer V: KAM1-C4-V-16-1-1A, 1pL hum; (NISP=1; $\mathrm{MNI}=1)$.

Ardenna pacifica, previously listed in the genus Puffinus, has a widespread breeding distribution in Eastern Polynesia, including in the Gambier Group (Thibault and Cibois, 2017).

\section{Procellariidae genus indet.}

\section{Material}

Onemea Site (190-12-TAR-6), Taravai Is. (Total $\mathrm{NISP}=11 ; \mathrm{MNI}=7$ ).

Layer II: TAR6-TP06-II-5-Fosse-46A-B, 1dL ulna; TAR6-TP11-II-3-19A-F, 1R3L scap; $\quad(\mathrm{NISP}=5$; $\mathrm{MNI}=3)$.

Layer II/III: TAR6-TP10-II/III-3-28A-E, 1R scap; $(\mathrm{NISP}=1 ; \mathrm{MNI}=1)$.

Layer III: TAR6-TP10-III-4-29A-E, 1sR hum; TAR6TP11-III-2-65A-M, 3R1L scap; (NISP=5; MNI=3).

Nenega-Iti Site (190-12-AGA-3), Agakauitai Is. (Total NISP=17; $\mathrm{MNI}=5$ ).

Layer IV: AGA3-E9-IV2-11-5-1A, 1sL hum; AGA3F9-IV2-11-5-1L, 1pR hum; AGA3-F9-IV2-11-5-1Q, 1pL ulna; AGA3-F9-IV2-11-5-1R, 1dL ulna; AGA3F9-IV2-11-5-1S, 1dL cmc; AGA3-D9-IV3-19-1-1C, 1sR hum; AGA3-D9-IV3-19-1-1D, 1sR ulna; AGA3-F9-IV3-12-8-1U, 1dR rad; AGA3-D9-IV4-205-1G, 1pL hum; AGA3-D9-IV4-20-5-1A, dL hum; AGA3-D9-IV4-21-5-1K, 1sR ulna; AGA3-D9-IV421-5-1L, 1sR ulna; AGA3-F9-IV4-13-1-1M, 1pR rad; AGA3-F9-IV4-13-1-1N, 1pL rad; AGA3-F9IV4-13-6-1E, 1dR hum; AGA3-F9-IV4-13-6-1F, 1 pL hum; AGA3-F9-IV4-13-6-1G, $1 \mathrm{~L}$ phal II.1; (NISP=17; MNI=5, allowing for sub-layers).

Kitchen Cave (190-04-KAM-1), Kamaka Is. (Total $\mathrm{NISP}=1 ; \mathrm{MNI}=1$ ).

Layer V: KAM1-C4-V-14-8-15B, 1dL cmc; $(\mathrm{NISP}=1 ; \mathrm{MNI}=1)$.

Under this taxon, we list bones belonging to either petrels or shearwaters, but their fragmentary nature precludes a more precise identification.
Family OCEANITIDAE Salvin, 1896

Genus NESOFREGETTA Mathews, 1912

Nesofregetta fuliginosa (Gmelin, 1789), Polynesian Storm-Petrel

\section{Material}

Onemea Site (190-12-TAR-6), Taravai Is. (Total $\mathrm{NISP}=1 ; \mathrm{MNI}=1)$.

Layer III: TAR6-TP10-III-4-29A-H, 1dR tt; (NISP=1; $\mathrm{MNI}=1$ ).

Kitchen Cave (190-04-KAM-1), Kamaka Is. (Total $\mathrm{NISP}=37$; $\mathrm{MNI}=15$, allowing for sub-layers).

Layer I: KAM1-C3-I-1-4-11*, $1 \mathrm{R}$ fem; $(\mathrm{NISP}=1$; $\mathrm{MNI}=1$ ).

Layer III: KAM1-B2-III1-3-5-39B*, 1dL tt; KAM1B4-III1-4-7-7B, 1dL tt; KAM1-B2-III2-5-3-161A*, 1dL tmt; KAM1-B2-III2-5-3-161B*, 1dR tt; KAM1B2-III2-5-3-161C, 1R ulna; KAM1-B3TP1-III2-68A-A*, 1L tmt; KAM1-B3TP1-III2-6-8A-C*, 1L rad; KAM1-B3TP1-III2-7-5A-D*, 1pL tmt; KAM1-C3-III28-7-58A*, 1pR tmt; KAM1-C3-III2-9-2-27* $1 \mathrm{~L} \mathrm{cmc;}$ KAM1-C4-III2-9-4-36A*, 1dL tt; KAM1-C4-III2-9-4$36 \mathrm{~B}^{*}, 1 \mathrm{dR} \mathrm{tmt}$; (NISP=12; MNI=5).

Layer IV1: KAM1-B2-IV1-7-1-23A*, 1dR tmt; KAM1-B3TP1-IV1-8-3A-A*, 1L tmt; KAM1-B3TP1IV1-9-6QQ-A, 1dL tmt; KAM1-B3TP1-IV1-9-6QQ$B$, 1L ulna; KAM1-B3TP1-IV1-10-4SS-A*, 1dL tt; KAM1-B3TP1-IV1-11-1A-A*, 1dL tt; KAM1-B4-IV110-3-1A*, 2dR tt; KAM1-B4-IV1-10-3-1C*, $1 \mathrm{~L} \mathrm{cmc;}$ KAM1-C3-IV1-10-4-45A*, 1dL tmt; KAM1-C3-IV111-1-37A, 1R hum; KAM1-C4-IV1-11-3-62A*, 1dR1pL tmt; KAM1-B2-IV2-10-3-20*, 1dR tt; KAM1-B4-IV2-12-3-38A*, 1dR tmt; KAM1-C4-IV212-4-1*, 2dL tt; KAM1-C4-IV2-13-4-39A*, 1dL tmt; (NISP=18; $\mathrm{MNI}=6$, allowing for sub-layers).

Layer V: KAM1-B3TP1-V-14-4A-A, 1dL hum; KAM1-B3TP1-V-15-3A-A*, 1dL tmt; KAM1-B4-V13-4-1A*, 1L tmt; KAM1-C3-V-14-3-23A, 1L fem; KAM1-C3-V-14-3-23B, 1R cmc; KAM1-C3-V-15-6$25 \mathrm{~A}^{*}, 1 \mathrm{dL} \mathrm{tmt}$; (NISP=6; $\mathrm{MNI}=3$ ).

Nesofregetta fuliginosa has a widespread breeding distribution in Eastern Polynesia on islands free from predators, including the Gambier Group (Thibault and Cibois, 2017). Metrics for these specimens are shown in Table 3.

Order PELECANIFORMES Sharpe, 1891

Family ARDEIDAE Leach, 1820

Genus EGRETTA T. Forster, 1817

Egretta sacra (Gmelin, 1789), Pacific Reef Egret

\section{Material}

Nenega-Iti Site (190-12-AGA-3), Agakauitai Is. (Total NISP=1; $\mathrm{MNI}=1$ ). 
TABLE 3. Summary statistics of measurements $(\mathrm{mm})$ of Nesofregetta fuliginosa from Kitchen Cave, Gambier Group (KAM-1). Specimens used: see * in specimen list. Abbreviations: DW, distal width; SW, minimum shaft width; SD, shaft depth at point of minimum SW; PW, proximal width; TL, Total length.

\begin{tabular}{lccccccccc}
\hline & \multicolumn{3}{c}{ Tibiotarsus } & \multicolumn{3}{c}{ Tarsometatarsus } & \multicolumn{2}{c}{ Radius } & \multicolumn{2}{c}{ Carpometacarpus } \\
\hline \multirow{3}{*}{ Mean } & DW & SW & SD & TL & PW & DW & TL & TL & PW \\
Min & 4.6 & 2.6 & 2.0 & 46.9 & 5.5 & 6.5 & 28.9 & 20.1 & 6.1 \\
Max & 4.3 & 2.4 & 1.9 & 45.8 & 5.1 & 6.2 & & & 6.1 \\
Std Dev & 4.8 & 2.7 & 2.2 & 47.7 & 5.8 & 6.8 & & & 6.1 \\
Count & 0.14 & 0.08 & 0.10 & 0.98 & 0.24 & 0.21 & & & 2
\end{tabular}

Layer II: AGA3-E9-II2-5-7-72C, 1dL tt; $(\mathrm{NISP}=1$; $\mathrm{MNI}=1$ ).

This species is widespread in the Pacific, with birds smaller in Eastern Polynesia than in the West (Thibault and Cibois, 2017). It is a common breeding species in the Tuamotu Archipelago, but in the Gambier Group, breeding is limited to a few pairs (Thibault and Cibois, 2017).

Family FREGATIDAE Degland \& Gerbe, 1867 Genus FREGATA Lacépède, 1799

Fregata ariel (Gray, 1845), Lesser Frigatebird

\section{Material}

Kitchen Cave (190-04-KAM-1), Kamaka Is. (Total $\mathrm{NISP}=1 ; \mathrm{MNI}=1$ ).

Layer III: KAM1-C3-III2-7-2-56A, 1pR hum; $(\mathrm{NISP}=1 ; \mathrm{MNI}=1)$.

This species breeds in widespread localities in Eastern Polynesia including the southern part of the Tuamotu Archipelago, but is only a visitor to the Gambier Group (Thibault and Cibois, 2017).

Fregata minor (Gmelin, 1789), Great Frigatebird

\section{Material}

Onemea Site (190-12-TAR-6), Taravai Is. (Total $\mathrm{NISP}=2 ; \mathrm{MNI}=1)$.

Layer III: TAR6-TP11-III-2-65A-G, 1dL cmc, pt 1R furcula; (NISP=2; $\mathrm{MNI}=1)$.

Kitchen Cave (190-04-KAM-1), Kamaka Is. (Total $\mathrm{NISP}=3$; $\mathrm{MNI}=2$ ).

Layer III: KAM1-B4-III1-3-14-1A, 1R cor, 1dR ulna; KAM1-B3TP1-III2-6-8A-E, 1dL tt; (NISP=3; $M N I=2$, allowing for sub-layers).

This species breeds in widespread localities in Eastern Polynesia including the Gambier Group (Thibault and Cibois, 2017).

Order CHARADRIIFORMES Huxley, 1867

Family LARIDAE Rafinesque, 1815

Genus GYGIS Wagler, 1832

Gygis alba (Sparrman, 1786), White Tern

\section{Material}

Onemea Site (190-12-TAR-6), Taravai Is. (Total $\mathrm{NISP}=66$; $\mathrm{MNI}=16$ ).

Layer II: TAR6-TP02-II-6-22-A, 1pR cor; TAR6TP02-II-6-22-B, 1 ant stern; TAR6-TP02-II-St.1-28, 1dR tt; TAR6-TP02-II-7-31-A, 1dL tt, 1L tmt; TAR6TP02-II-7-31-B, 2dR1dL cor, 1R1L scap, 1 ant stern; TAR6-TP05-II-1-15A-A, 1pL cor; TAR6TP05-II-2-25A-C, 1R cor; TAR6-TP05-II-3-31A-B, 1L cor; TAR6-TP05-II-6-55A-F, 1R cmc,1R1L cor; TAR6-TP06-II-4-37A-B, 1R cmc; TAR6-TP11-II-16A-C, 1R scap; TAR6-TP11-II-9-56A-A, 1R cor; $(\mathrm{NISP}=20 ; \mathrm{MNI}=6)$.

Layer II/III: TAR6-TP10-II/III-3-28A-D, 1L phal II.1; $(\mathrm{NISP}=1 ; \mathrm{MNI}=1)$.

Layer III: TAR6-TP02-III-8-33-A, 2R1L dent, 2R2L art pt mand, $1 \mathrm{R} 1 \mathrm{~L} 1 \mathrm{pL}$ cor, $2 \mathrm{dR} 2 \mathrm{dL}$ tt, $1 \mathrm{sR} \mathrm{tmt;}$ TAR6-TP02-III-8-33-B, 2 ant stern, 1 pmx, 1 mand tip, 1R1L scap, 2dR1dL cor; TAR6-TP02-III-8-35A, 1pL hum, 1R tt, 1R1L cor; TAR6-TP02-III-8-35B, 1R1L scap, 1 ant stern; TAR6-TP02-III-9-39-A, 2R1L cor; TAR6-TP02-III-9-39-B, 1R scap, 1 ant stern; TAR6-TP06-III-2-61A, 1pL hum; TAR6TP06-III-3-64A-B, 1L cmc; TAR6-TP11-III-2-65A-L, 2R1L scap 2R1L cor; (NISP=44; $\mathrm{MNI}=8$ ).

Unknown (Layer X): TAR6-TP10-X-St.1-34A-C, $1 \mathrm{dL}$ ulna; (NISP=1; MNI=1).

Kitchen Cave (190-04-KAM-1), Kamaka Is. (Total $\mathrm{NISP}=7 ; \mathrm{MNI}=4)$.

Layer III: KAM1-B2-III1-4-3-107B, 1R phal II.1; KAM1-B4-III2-6-6-45A, 1dR ulna; KAM1-B4-III2-79-1A, 1R hum; (NISP=3; MNI=2, allowing for sublayers).

Layer IV: KAM1-B2-IV1-7-1-23D, 1dR tt; KAM1B3TP1-IV1-9-6QQ-C, 1L cmc; KAM1-B3TP1-IV110-4SS-B, $1 \mathrm{pL}$ ulna; (NISP=3; MNI=1).

Layer V: KAM1-B3TP1-V-15-3A-C, $1 \mathrm{dL}$ rad; $(\mathrm{NISP}=1 ; \mathrm{MNI}=1)$.

This widespread species breeds in most part of Eastern Polynesia, the Gambier Group included (Thibault and Cibois, 2017). 


$$
\begin{aligned}
& \text { Laridae magn. Procelsterna cerulea (Bennett, } \\
& \text { 1840), Blue Noddy }
\end{aligned}
$$

\section{Material}

Nenega-Iti Site (190-12-AGA-3), Agakauitai Is. (Total NISP $=2 ; \mathrm{MNI}=1$ )

Layer II: AGA3-E13-II2-4-7-1A, 1R ulna; AGA3E13-II2-4-7-1B, 1pR rad; (NISP=2; MNI=1).

Kitchen Cave (190-04-KAM-1), Kamaka Is. (Total $\mathrm{NISP}=6 ; \mathrm{MNI}=3$ ).

Layer III: KAM1-B4-III1-3-14-1C, 1dR tt; KAM1-C4III2-6-3-8A, 1dR hum; KAM1-B3TP1-III2-7-5A-B, 1L cmc; KAM1-C4-III2-7-5-17A, 1R cor, 1R phal II.1; (NISP=5; $\mathrm{MNI}=2)$.

Layer VI: KAM1-B3TP1-VI-16-4A-B, 1pL rad; $(\mathrm{NISP}=1 ; \mathrm{MNI}=1)$.

These bones are too fragmentary for a certain taxonomic assignment from morphology, but they are most similar to bones of terns and based on size are likely to be from Procelsterna cerulea, which is widespread in the Tuamotu Archipelago (Thibault and Cibois, 2017). However, the Grey Noddy, $P$. albivitta, has a more southerly breeding distribution that includes the Austral and Pitcairn groups (Dickinson and Remsen, 2013) and, in the Gambier Group, birds have a plumage intermediate between the two taxa (Thibault and Cibois, 2017), precluding a certain specific assignment, if these taxa are indeed distinct.

\section{Summary}

The NISP and MNI generated by taxa for each stratigraphic unit are given in Appendix 1 for the faunas from the three sites from the Gambier Group reported here, Onemea (Taravai Is.), Nenega-Iti Site (Agakauitai Is.) and Kitchen Cave (Kamaka Is.). Table 4 provides a summary of the total NISP and MNI for each taxon, calculated by totalling the $\mathrm{MNI}$ from all stratigraphic units by site. A total of 647 bones from 192 individuals were identified to family-level or lower, and were distributed by site as follows: Onemea 419 bones, MNI of 102; Nenega-Iti Site 139 bones, MNI of 44; Kitchen Cave Site 89 bones MNI of 46 . These minimally represent 15 species of seabirds and six of land birds, one being the prehistorically introduced junglefowl (Gallus gallus). With the addition of the previously identified bones (Table 5), the proportions of seabirds to land birds and of the various families was calculated and shown in Figure 4. This reveals that seabirds dominate the faunas and among those, procellariids predominate. Land bird faunas are too small for discernment of meaningful trends, but columbids dominate the main assemblages.

\section{DISCUSSION}

The new investigations reported here considerably add to the known prehistoric avifaunal record for the Gambier Group, which until now was based on 215 identified bones (Steadman and Justice, 1998; Steadman, 2006). Our new data are compiled in Table 5 with those of Steadman and Justice (1998), and the modern and historic record of birds from the Gambier Group (Thibault and Cibois, 2017), to estimate the former diversity of breeding taxa.

We report minimally 14 species of seabird in the prehistoric record of the Gambier Group (Table 5), including three (Pseudobulweria sp., and Pterodroma magn. $P$. heraldica and $P$ t. magn. $P$. leucoptera) that have not been previously recorded in the archaeological faunas, although Steadman and Justice (1998) noted indeterminate small to large species of Pterodroma. Of these oceanic birds, minimally seven are procellariids (Figure 5 ), with the proviso that we consider the previous records of Bulweria sp. cf. B. fallax and Puffinus Iherminieri to be equivalent to Pseudobulweria sp. indet. and Puffinus bailloni respectively. However, we reiterate that because of the cryptic nature of procellariids, more than one species may be represented by our taxa that reflect size classes, e.g., Pterodroma magn. leucoptera and $P$. magn. heraldica. For the latter, Pterodroma ultima, P. neglecta and P. heraldica all breed in the Gambier Group, although others, as noted in the Introduction (above), are probable visitors (Thibault and Cibois, 2017). In order to conservatively establish the diversity of former breeding seabirds, we assume that the taxon Pterodroma magn. leucoptera, which was relatively abundant in the fauna from Onemea (Taravai), represents one breeding species, although several similar-sized small Pterodroma species certainly feed seasonally in the oceans about the Gambier Group (see Introduction). This species is likely to be Pterodroma brevipes, or a closely related taxon, as this species has the closest breeding populations today (Thibault and Cibois, 2017).

We do not accept the interpretation that the record of Puffinus tenuirostris reflects an extirpated population (Steadman, 2006: 237), as this species breeds in the millions in cool-temperate climates about Australia and migrates to the northern Pacific annually, passing on their return through eastern Polynesia (Marchant and Higgins, 1993), as noted by Steadman and Justice (1998). It is therefore likely that the few birds represented, if correctly identified, are from birds caught when 
TABLE 4. Summary of data for bird bones identified from each site in this study, showing NISP (MNI), where NISP is the Number of Identifiable Specimens and MNI the Minimum Number of Individuals, determined separately for each layer and summed for the site. Taxa in brackets are not necessarily different from those more precisely identified. $\dagger$ is extinct.

\begin{tabular}{|c|c|c|c|c|}
\hline Taxa & $\begin{array}{c}\text { Onemea Site } \\
\text { (Taravai) }\end{array}$ & $\begin{array}{c}\text { Nenega-lti Site } \\
\text { (Agakauitai) }\end{array}$ & $\begin{array}{c}\text { Kitchen Cave Site } \\
\text { (Kamaka) }\end{array}$ & $\begin{array}{l}\text { Total NISP } \\
\text { (MNI) }\end{array}$ \\
\hline \multicolumn{5}{|l|}{ Seabirds } \\
\hline †Pseudobulweria sp. & $158(26)$ & $82(18)$ & - & $240(44)$ \\
\hline Pterodroma magn. P. heraldica & $55(8)$ & $6(3)$ & $4(2)$ & $65(13)$ \\
\hline Pterodroma magn. P. leucoptera & $22(5)$ & - & - & $22(5)$ \\
\hline (Pterodroma sp. indet.) & $7(3)$ & $1(1)$ & $1(1)$ & $9(5)$ \\
\hline Puffinus magn. P. bailloni & $26(8)$ & $6(4)$ & $11(6)$ & $43(18)$ \\
\hline Puffinus nativitatis & $28(5)$ & $9(3)$ & $1(1)$ & $38(9)$ \\
\hline (Puffinus sp. indet.) & - & $1(1)$ & - & $1(1)$ \\
\hline Ardenna pacifica & $12(4)$ & $3(1)$ & $2(2)$ & $17(7)$ \\
\hline (Procellariidae spp.) & $11(7)$ & $17(5)$ & $1(1)$ & $28(13)$ \\
\hline Nesofregetta fuliginosa & $1(1)$ & - & $37(15)$ & $38(16)$ \\
\hline Phaethon lepturus & $20(4)$ & $5(2)$ & $8(5)$ & $33(11)$ \\
\hline Phaethon rubricauda & $9(3)$ & - & $1(1)$ & $10(4)$ \\
\hline Fregata ariel & - & - & $1(1)$ & $1(1)$ \\
\hline Fregata minor & $2(1)$ & - & $3(2)$ & $5(3)$ \\
\hline Gygis alba & $66(16)$ & - & $7(4)$ & $73(20)$ \\
\hline Larid magn. Procelsterna cerulea & - & $2(1)$ & $6(3)$ & $8(4)$ \\
\hline \multicolumn{5}{|l|}{ Land birds } \\
\hline Gallus gallus & $2(2)$ & $2(2)$ & - & $4(4)$ \\
\hline †Bountyphaps sp. cf. B. obsoleta & - & $1(1)$ & $4(2)$ & $5(3)$ \\
\hline †Ducula tihonireasini & $6(3)$ & - & - & $6(3)$ \\
\hline Ptilinopus sp. indet. & $3(3)$ & - & - & $3(3)$ \\
\hline (Columbidae gen. et sp. indet.) & - & - & $3(1)$ & $3(1)$ \\
\hline Egretta sacra & - & $1(1)$ & - & $1(1)$ \\
\hline Total determinate NISP (MNI) & $419(102)$ & $139(44)$ & $89(46)$ & $647(192)$ \\
\hline
\end{tabular}

attracted to the colonies of resident procellariids as has been regularly reported (e.g., Warham, 1990; Imber et al., 1991).

To establish the likely extent of the actual diversity of breeding seabirds, we have added to Table 5 other taxa known to breed in the Gambier Group (Thibault and Cibois, 2017). This results in the addition of three sulids and the tern Anous minutus. Steadman (2006) listed Pterodroma lessoni from the Gambier Group, but this species is a non-breeding visitor and so we exclude it from the list of resident seabirds. Similarly, all other procellariiform non-breeding visitors to Eastern Polynesian waters near the Gambier Group, e.g., Pelagodroma marina, Fregetta grallaria, Macronectes giganteus, Pterodroma cookii, Pt. atrata, Pt. alba, Pt. externa, Pt. cervicalis, Pt. macroptera, Procellaria cinerea, Pr. aequinoctialis, Pr. parkin- soni, Ardenna grisea, A. carneipes, [see Thibault and Cibois (2017)] are not listed. All might be expected to contribute rare specimens to an avifauna in the region. In summary, the 19 oceanic seabird taxa listed as breeding in Table 5 equate minimally to 21 species likely to have been breeding in the Gambier Group.

There are perhaps minimally a further 12 species of land birds in the original breeding avifauna of the Gambier Group. Dominating the prehistoric record are rare bones of five species of columbids. Two of these are extinct and newly recorded for the Group, an imperial pigeon Ducula tihonireasini n. sp. and Bountyphaps sp. cf. B. obsoleta known originally from Henderson Island. The new species of Ducula is most likely a local endemic species given that it differs from congeneric taxa on Henderson Island and in the Marquesas (Worthy and 
TABLE 5. Past and present distribution of birds in the Gambier Group. Data is from this study (bold) with additional data for Aukena, Mangareva and Kamaka from Steadman and Justice (1998) in non-bold text. Species status is from Thibault and Cibois (2017), B, breeding; $\mathrm{H}$, historic record; M, migrant; e, extirpated; $\mathrm{E}$, extinct; v, visitor. MNI is between brackets. MNI for the data from Steadman and Justice (1998) is derived by the separate additive treatment of each layer and sub-layer, but because elements were not reported to side, MNI for an element within a stratum is assessed by dividing the reported number by two, so 4 humeri would be $\mathrm{MNI}=2$. Taxa in brackets are not necessarily different from those more precisely identified. Taxa in bold are introduced species. † means extinct, $† B$ is extinct breeding population.

\begin{tabular}{|c|c|c|c|c|c|c|c|}
\hline \multirow[b]{2}{*}{ Taxa } & \multirow{2}{*}{$\begin{array}{l}\text { Modern Status } \\
\text { Gambier Group }\end{array}$} & \multicolumn{5}{|c|}{ Prehistoric Records } & \multirow[b]{2}{*}{ Total } \\
\hline & & Agakauitai & Aukena & Kamaka & Mangareva & Taravai & \\
\hline OCEANIC SEABIRDS & & & & & & & $205+632(93+172)$ \\
\hline Procellariidae & & & & & & & $135+464(52+116)$ \\
\hline$\dagger P$ seudobulweria sp. & $E, B$ & $82(18)$ & $?$ & - & - & $158(26)$ & $240(44)$ \\
\hline Bulweria sp. cf. B. fallax 1 & - & - & $1(1)$ & - & - & - & $1(1)$ \\
\hline $\begin{array}{l}\text { Pterodroma magn. } P . \\
\text { heraldica }\end{array}$ & B & $6(3)$ & $?$ & $4(2)$ & - & $55(8)$ & $65(13)$ \\
\hline $\begin{array}{l}\text { Pterodroma magn. } P . \\
\text { leucoptera }\end{array}$ & $v, † B$ & - & - & - & - & $22(5)$ & $22(5)$ \\
\hline (Pterodroma sp.) & - & $1(1)$ & $7(3)$ & $\begin{array}{l}34+1(10 \\
+1)\end{array}$ & - & $7(3)$ & $41+9(13+5)$ \\
\hline Puffinus magn. P. bailloni & B & $6(4)$ & - & $11(6)$ & - & $26(8)$ & $43(18)$ \\
\hline Puffinus Iherminieri 2 & - & - & $1(1)$ & $16(9)$ & - & - & $17(10)$ \\
\hline Puffinus nativitatis & B & $9(3)$ & $9(3)$ & $\begin{array}{c}44+1 \\
(12+1)\end{array}$ & - & $28(5)$ & $53+38(15+9)$ \\
\hline (Puffinus sp.) & - & $1(1)$ & - & $1(1)$ & - & - & $1+1(1+1)$ \\
\hline Ardenna pacifica & $\mathrm{B}$ & $3(1)$ & - & $5+2(2+2)$ & - & $12(4)$ & $5+17(2+7)$ \\
\hline Ardenna tenuirostris & M & - & $2(1)$ & $4(3)$ & - & - & $6(4)$ \\
\hline (Procellariidae spp.) & - & $17(5)$ & - & $11+1(6+1)$ & - & $11(7)$ & $11+29(6+13)$ \\
\hline \multicolumn{8}{|l|}{ Oceanitidae } \\
\hline Nesofregetta fuliginosa & B & - & - & $\begin{array}{c}4+37 \\
(4+15)\end{array}$ & - & $1(1)$ & $4+38(4+16)$ \\
\hline Phaethontidae & & & & & & & $32+43(15+13)$ \\
\hline Phaethon lepturus & B & $5(2)$ & - & $13+8(7+5)$ & - & $20(4)$ & $13+33(7+11)$ \\
\hline Phaethon rubricauda & B & - & $4(2)$ & $15+1(6+1)$ & - & $9(1)$ & $19+10(8+2)$ \\
\hline \multicolumn{8}{|l|}{ Sulidae } \\
\hline Sula dactylatra & $\mathrm{B}$ & - & - & - & - & - & \\
\hline Sula leucogaster & $\mathrm{B}$ & - & - & - & - & - & \\
\hline Sula sula & $\mathrm{B}$ & - & - & - & - & - & \\
\hline Fregatidae & & & & & & & $13+6(9+3)$ \\
\hline Fregata ariel & $v$ & - & $2(1)$ & $1(1)$ & - & - & $2+1(1+1)$ \\
\hline Fregata minor & $\mathrm{B}$ & - & - & $11+3(8+1)$ & - & $2(1)$ & $11+5(8+2)$ \\
\hline Laridae & & & & & & & $21+81(14+24)$ \\
\hline Thalasseus bergii & $\mathrm{v}, ? \mathrm{~B}$ & - & - & - & - & & \\
\hline Anous minutus & $\mathrm{B}$ & - & - & - & - & - & \\
\hline Anous stolidus & $\mathrm{B}$ & - & - & $6(4)$ & - & - & $6(4)$ \\
\hline Procelsterna cerulea & B & - & - & $1(1)$ & - & - & $1(1)$ \\
\hline $\begin{array}{l}\text { Larid magn. Procelsterna } \\
\text { cerulea }\end{array}$ & - & $2(1)$ & - & $6(3)$ & - & - & $8(4)$ \\
\hline Gygis alba & B & - & - & $14+7(9+4)$ & - & $66(16)$ & $14+73(9+20)$ \\
\hline
\end{tabular}


TABLE 5 (continued).

\begin{tabular}{|c|c|c|c|c|c|c|c|}
\hline \multirow[b]{2}{*}{ Taxa } & \multirow{2}{*}{$\begin{array}{c}\text { Modern Status } \\
\text { Gambier Group }\end{array}$} & \multicolumn{5}{|c|}{ Prehistoric Records } & \multirow[b]{2}{*}{ Total } \\
\hline & & Agakauitai & Aukena & Kamaka & Mangareva & Taravai & \\
\hline LAND BIRDS & & & & & & & $10+22(9+15)$ \\
\hline \multicolumn{8}{|l|}{ Phasianidae } \\
\hline Gallus gallus & $\mathrm{B}, \mathrm{H}$ & $2(2)$ & - & $3(3)$ & $1(1)$ & $2(2)$ & $4+4(4+4)$ \\
\hline Columbidae & & & & & & & $3+17(3+10)$ \\
\hline $\begin{array}{l}\text { †Bountyphaps sp. cf. B. } \\
\text { obsoleta }^{3}\end{array}$ & $E$ & $1(1)$ & - & $2+4(2+2)$ & - & - & $2+5(2+3)$ \\
\hline †Alopecoenas erythropterus & $\mathrm{e}, ? \mathrm{H}$ & - & - & $1(1)$ & - & - & $1(1)$ \\
\hline$\dagger$ Ducula tihonireasini & $\mathrm{E}, \mathrm{H}$ & - & - & - & - & $6(3)$ & $6(3)$ \\
\hline †Ptilinopus sp. indet. & $\mathrm{e}, \mathrm{H}$ & - & - & - & - & $3(3)$ & $3(3)$ \\
\hline$\dagger$ (Columbidae genera indet.) & $E$ & - & - & $3(1)$ & - & - & $3(1)$ \\
\hline Columba livia & B & - & - & - & - & - & - \\
\hline \multicolumn{8}{|l|}{ Ardeidae } \\
\hline Egretta sacra & B & $1(1)$ & - & $1(1)$ & - & - & $1+1(1+1)$ \\
\hline \multicolumn{8}{|l|}{ Rallidae } \\
\hline Zapornia tabuensis & $\mathrm{e}, \mathrm{H}$ & - & - & - & - & - & - \\
\hline \multicolumn{8}{|l|}{ Charadriidae } \\
\hline Pluvialis fulva & M & - & - & - & - & - & - \\
\hline \multicolumn{8}{|l|}{ Scolopacidae } \\
\hline Numenius tahitiensis & M & - & - & $2(1)$ & - & - & $2(1)$ \\
\hline Tringa incana & M & - & - & - & - & - & - \\
\hline Prosobonia parvirostris & $\mathrm{e}, \mathrm{H}$ & - & - & - & - & - & - \\
\hline Calidris alba & M & - & - & - & - & - & - \\
\hline \multicolumn{8}{|l|}{ Cuculidae } \\
\hline Urodynamis taitensis & M & - & - & - & - & - & - \\
\hline \multicolumn{8}{|l|}{ Alcedinidae } \\
\hline †Todiramphus gambieri & $\mathrm{E}, \mathrm{H}$ & - & - & - & - & - & - \\
\hline \multicolumn{8}{|l|}{ Acrocephalidae } \\
\hline$\dagger$ Acrocephalus astrolabii & $\mathrm{E}, \mathrm{H}$ & - & - & - & - & - & - \\
\hline Acrocephalus atyphus & $\mathrm{v}, \mathrm{H}$ & - & - & - & - & - & - \\
\hline \multicolumn{8}{|l|}{ Pachycephalidae } \\
\hline "Pachycephala"gambierana & $\mathrm{E}$ ?, H? & - & - & - & - & - & - \\
\hline
\end{tabular}

1. We consider it most likely that this specimen identified by Steadman and Justice (1998) belongs to the taxon identified here as Pseudobulweria sp. indet.

2. The bones referred by Steadman (2006) to Puffinus Iherminieri were identified before separation of that Atlantic Ocean taxon from the Pacific birds, so they would now be listed in our taxon Puffinus magn. P. bailloni. Puffinus bailloni is a common breeding bird in the Gambier Group but the similar sized $P$. auricularis myrtae is a likely visitor to the area and would not be distinguished on bones.

3. We consider it more likely (as discussed above) that the bones referred to Alopecoenas (=Gallicolumba) nui by Steadman and Justice (1998) from Kamaka Island belong to the same taxon as those we refer to Bountyphaps sp. cf. obsoleta, so they are included here. 

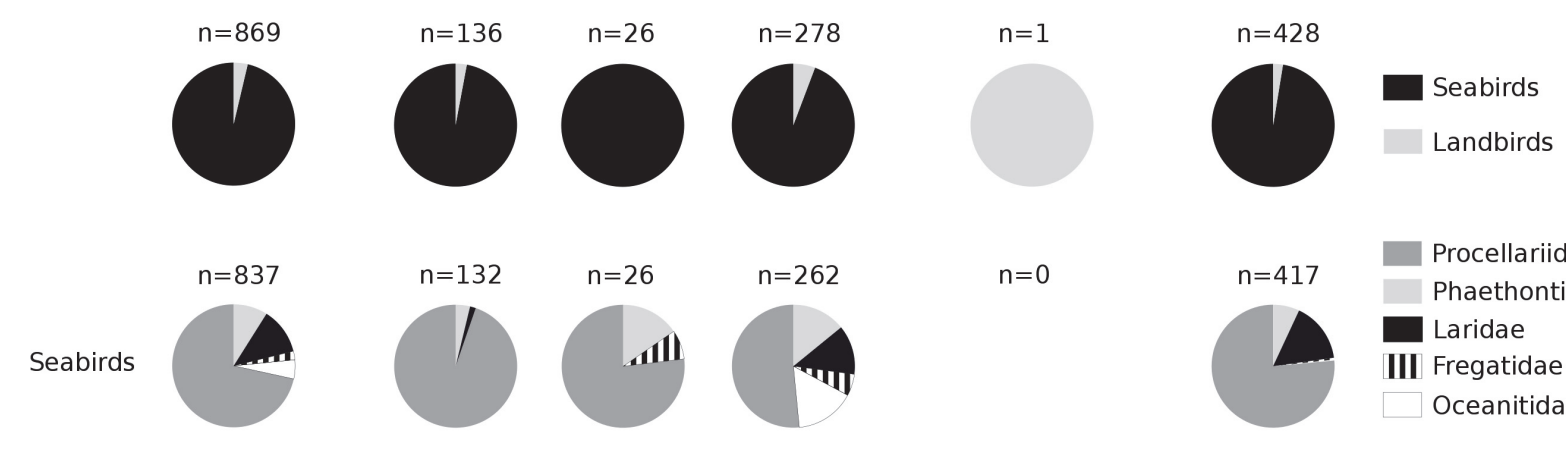

Procellariidae Phaethontidae

Laridae

III Fregatidae

Oceanitidae

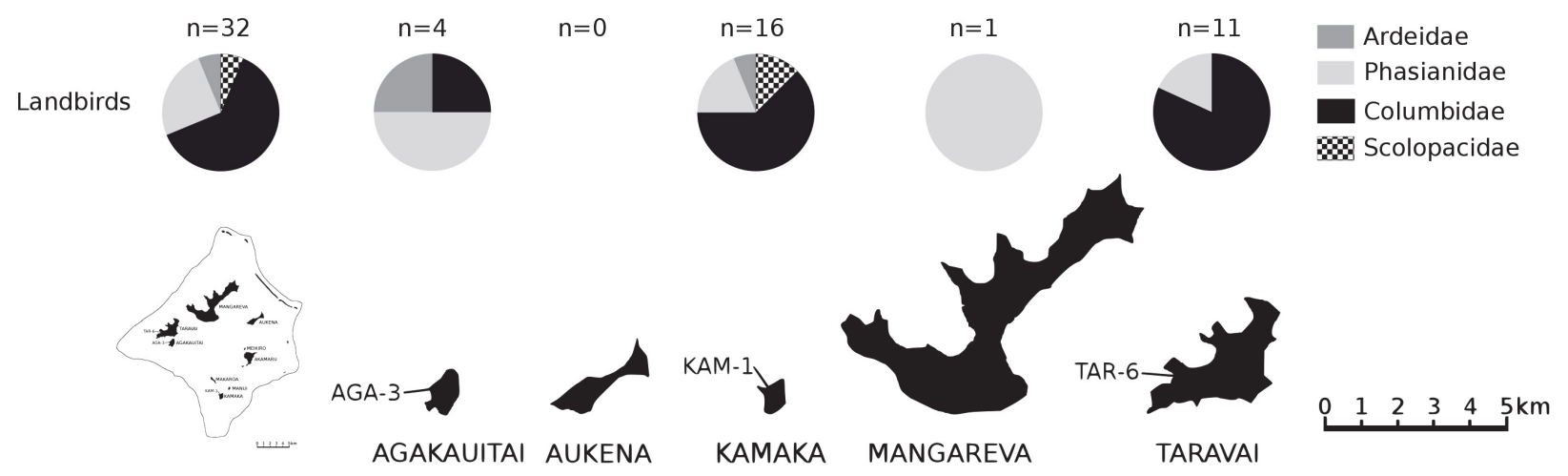

FIGURE 4. Relative proportions of seabirds and land birds, and of the constituent families for each group, for the Gambier Group as a whole (left) and individual islands/sites. Data is based on the 647 bones reported herein plus the 215 specimens previously reported as compiled in Table 5.

Wragg, 2008). However, the same may not be the case for Bountyphaps, under which taxon we list the specimens identified as Gallicolumba nui by Steadman and Justice (1998), see above in species accounts. Caution is required in interpreting the presence of Bountyphaps in sites on Kamaka and Agakauitai as representing an autochthonous population for two reasons. Firstly, these sites are not as old (Anderson et al., 2003; Kirch et al., 2010) as the Onemea site on Taravai, where Bountyphaps was not found despite a large sample of bird bones. Secondly, the early Polynesian colonisers were adept at transporting birds, having introduced Gallus to the Gambier Group in the earliest period of colonisation (Green and Weisler, 2004) and there is ample evidence of various commodities being transported back and forth from the Pitcairn Group around AD 1000 (Green and Weisler, 2002). This includes basalt tools with a Pitcairn source found in Aukena Rockshelter (GA-1) and on Agakauitai Island (Green and Weisler, 2002). This evidence of return voyaging from the Pitcairn Group makes it at least possible that the Bountyp- haps bones may represent birds imported from Henderson Island.

A further three smaller columbids have been extirpated from the Gambier Group but survive elsewhere: a ground dove Alopecoenas erythropterus, which possibly was reported historically (Thibault and Cibois, 2017), a fruit dove Ptilinopus sp. indet. and a species that perhaps was a cuckoo dove Macropygia sp.

The columbids are all rare in the fauna and occur only in the oldest layers (Figure 5), so it is highly likely that other terrestrial taxa have escaped detection due to the relatively small sample sizes from the earliest stratigraphic contexts. The only other native land bird in the prehistoric record is the heron Egretta sacra, which still is a breeding species in the Gambier Group. To these prehistorically known land birds, a further six presumed breeding resident species only recorded historically $(\mathrm{H}-$ Table 5$)$, from the $18^{\text {th }}$ to early $20^{\text {th }}$ century) can be added (a rail, a shorebird - Prosobonia, a kingfisher and three passerines) for a total of 12 breeding species. It is notable that there are no fossil rails in the prehistoric record of the Gam- 


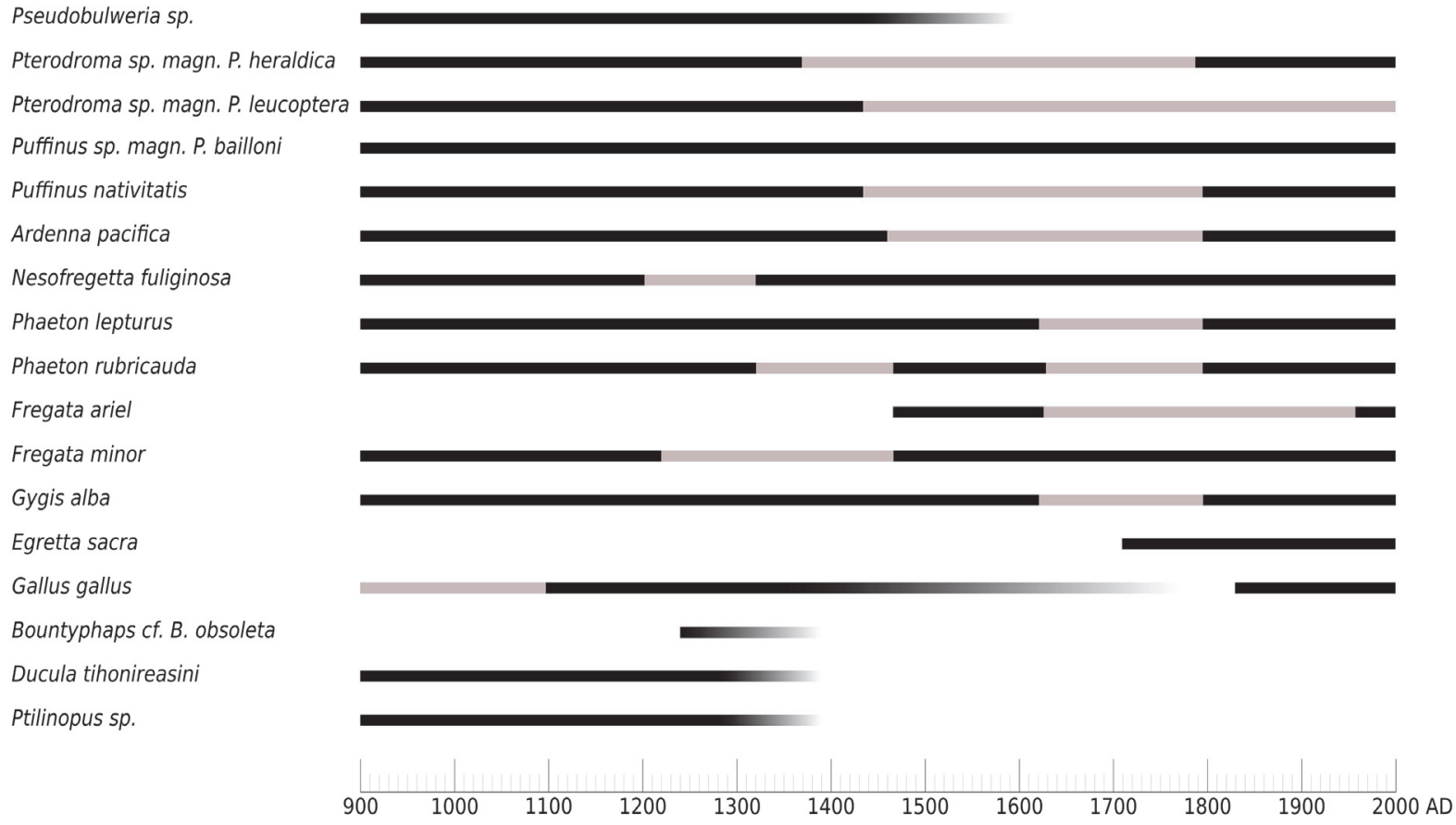

FIGURE 5. The recorded presence (black) or inferred presence but no data for (grey) of selected taxa through the archaeological record to the present in the Gambier Group showing how some taxa survived only into the fourteenth and fifteenth centuries.

bier Group, despite an historic record of spotless crake (Zapornia tabuensis) in the Gambier Group, and of this and other crakes having a widespread extant and prehistoric presence in Eastern Polynesia (Steadman, 2006; Thibault and Cibois, 2017). Similarly, it is surprising that no parrots have been found, despite the present and former abundance of several species of Vini lorikeet in the Tuamotu Archipelago and the Marquesas and of $V$. stepheni on Henderson in the Pitcairn Group (Steadman, 2006; Thibault and Cibois, 2017). Alongside these 12 breeding land birds, we list four migratory charadriid and scolopacid shorebirds, given that they live and feed on land in the coastal areas, and the migrant cuckoo (Urodynamis) known from contemporary observations (Table 5), although Numenius was recorded in the prehistoric record by Steadman and Justice (1998).

In summary, there were minimally 32 breeding species (20 oceanic seabirds, 12 land birds) in the pre-human avifauna of the Gambier Group. With the addition of five regular migrants (a cuckoo and four shorebirds), a total of minimally 37 species contributed to the resident avifauna in the Gambier Group. Of these, at least seven species, a seabird (a Pseudobulweria sp.), three columbids (one conservatively identified as Bountyphaps obsoleta, first described from Henderson Island (Worthy and Wragg, 2008), the new species Ducula tihonireasini described herein, and an undetermined taxon that possibly is a species of Macropygia) and three other land birds, are extinct. Five others have had their Gambier breeding populations extirpated (one seabird - Pterodroma magn. Pt. leucoptera, Prosobonia parvirostris, a rail, and two columbids). Of these columbids, the Ptilinopus sp. probably represents an extirpated population of Ptilinopus coralensis (Atoll Fruit Dove), which is widespread in the Tuamotu Archipelago; it has been recorded as a vagrant in the Gambier Group (Thibault and Cibois, 2017). Similarly, Alopecoenas erythropterus, while rare now, historically had a widespread breeding range in the Tuamotu Archipelago and in the Society Group (Thibault and Cibois, 2017). To these taxa can be added Gallus gallus, whose bones were rare in all sites but were found in the deeper layers, corroborating the observations of Steadman and Justice (1998) and indicating an early Polynesian introduction to the Gambier Group. However, this species was extirpated prior to European contact (Green and Weisler, 2004).

The size of our Gambier bird bone sample is small compared to other archaeological avifaunal assemblages, e.g., 42,213 bird bones from Hen- 
derson Island (Wragg, 1995), so it probably provides a still limited view of the past avifauna. Nevertheless, it suffices to show that the composition of original avifauna, especially of the seabirds, differed between islands in the Gambier Group, as it does currently (Waugh et al., 2013). For instance, on the adjacent Taravai and Agakauitai islands, Pterodroma magn. Pt. heraldica and Pseudobulweria sp. were common, but both were respectively, rare or absent on Kamaka Island. In contrast, Nesofregetta fuliginosa was abundant on Kamaka, while represented by just one bone on Taravai and none on Agakauitai. This pattern almost certainly reflects local breeding populations on these islands, and so colonies of a mediumsized petrel and a Pseudobulweria sp. were almost certainly on the adjacent islands on Taravai and Agakauitai, but not on Kamaka, a small species of Pterodroma only bred on Taravai, and $N$. fuliginosa only had a colony on Kamaka. In contrast, three species of shearwater, including a small species that was most likely P. bailloni, Puffinus nativitatis, and Ardenna pacifica probably bred on all three islands. The numbers of terrestrial birds are probably too small to determine whether there was any regionalisation of species within the Gambier Group. The observation that Ducula bones were only found on Taravai and those of Bountyphaps mainly on Kamaka is suggestive that these two islands had discrete columbid faunas. However, a Bountyphaps bone was also found on Agakauitai, which is very close to Taravai, thus it is most unlikely that Taravai really lacked Bountyphaps, and the apparent differences probably relate to the small sample sizes available of land birds.

Overall, the Gambier Group avifauna is most similar to that from prehistoric Henderson Island (Wragg, 1995; Steadman, 2006). Seabirds dominate the assemblages and land birds are relatively rare $(2.3-11.8 \%$ NISP; Steadman, 2006), with the higher values deriving from the non-archaeological assemblages reported by Wragg (1995). These higher numbers of land birds include Porzana atra as $4.4 \%$ of NISP, and four species of pigeon and one Vini parrot, and support the contention that the archaeological sample from the earliest humancontact layers for the Gambier Group is as yet too small to reveal the rail fauna and the relative frequencies of the represented columbids. The prehistoric avifaunas from the Marquesas are also similar to those from the Gambier Group in the rel- ative proportions of seabirds and their species diversity (Steadman, 2006). However, the land bird fauna is notably more diverse, with three rallids in two genera (Gallirallus, Zapornia [as Porzana]), six columbids in four genera, and three species of Vini parrots (Steadman, 2006). Heading west from the Gambier Group, the land bird faunas become increasingly diverse when large samples are available, with the Society Islands having three genera of rails among 25 species of land birds, Mangaia Island in the Cook Islands three genera and six species of rails among 27 land bird species (Steadman, 2006). Therefore, it is to either the Marquesas or Henderson Island that we can turn to estimate what is likely to be found in the Gambier Group when further archaeological excavations expand the recovery of larger and first contact avifaunas. Minimally one, but probably two rails and at least one Vini parrot arguably await discovery, and more bones will be required to better elucidate the columbids formerly present.

\section{ACKNOWLEDGEMENTS}

Excavations in the Gambier Islands that produced the avifaunal assemblages described herein were supported by grants from the U.S. National Science Foundation (grant no. BCS-1030049), and from the Wenner-Gren Foundation for Anthropological Research (grant no. 7177) to PVK. Permission to carry out archaeological research in the Gambiers was granted by the Ministry of Culture and Service de la Culture et du Patrimoine of the Government of French Polynesia, by the Délégation à la Recherche de la Polynésie Française, and by the Maire of the Gambier Commune. For assistance in arranging permits and facilitating the fieldwork, PVK thanks P. Frogier, J. Meyer, T. Maric, B. Mou, M. Richeton, the late T. Paeamara, E. and D. Sanford, R. Reasin, T. Reasin, and in particular the late T. Reasin. PVK thanks E. Conte and G. Molle for their assistance in helping to direct the excavations. École Normale Superieure de Lyon, France, facilitated the internship for SR at Flinders University that supported this research. For access to skeletal material, we thank P. Horton (South Australian Museum, Adelaide, South Australia); K. Roberts (Museum Victoria, Melbourne, Victoria); and A. Tennyson (Museum of New Zealand Te Papa Tongarewa, Wellington, New Zealand). 


\section{REFERENCES}

Anderson, A. 2001. The chronology of prehistoric colonization in French Polynesia, pp. 247-252. In Stevenson, C.M., Lee, G., and Morin, F.J. (eds.), Pacific 2000. Proceedings of the Fifth International Conference on Easter Island and the Pacific. Easter Island Foundation, The Easter Island Foundation, Bearsville Press, Los Osos, CA, 575 pp.

Anderson, A., 2003. Initial human dispersal in Remote Oceania: Pattern and explanation, pp 7184. In Sand, C. (ed.), Pacific Archaeology: Assessments and Prospects. Le Cahiers de l'Archéologie en Nouvelle-Caledonie, No. 15. Service des Musées de du Patrimoine, Noumea.

Anderson, A., Conte, E., Kirch, P.V., and Weisler, M.I. 2003. Cultural chronology in Mangareva (Gambier Islands), French Polynesia: Evidence from recent radiocarbon dating. The Journal of the Polynesian Society, 112(2):119-140. http://www.jstor.org/stable/20707144

Anderson, A. and Sinoto, Y. 2002. New radiocarbon ages of colonization sites in East Polynesia. Asian Perspectives, 41:242-257. https://doi.org/10.1353/asi.2003.0002

Athens, J.S., Rieth, T.M., and Dye, T.S. 2014. A paleoenvironmental and archaeological modelbased age estimate for the colonization of Hawai'i. American Antiquity, 79:144-155. https:// doi.org/10.7183/0002-7316.79.1.144

Balouet, J.C. and Olson, S.L. 1987. An extinct species of giant pigeon (Columbidae: Ducula) from archaeological deposits on Wallis (Uvea) Island, South Pacific. Proceedings of the Biological Society of Washington, 100:769-775. https://archive.org/details/biostor-74779

Beechey, F.W. 1832. Narrative of a voyage to the Pacific and Beering's Strait, to cooperate with the Polar Expeditions: Performed in His Majesty's Ship Blossom, under the command of Captain F. W. Beechey, R.N., F.R.S. in the years 1825, 26, 27, 28. Carey and Lea, Philadelphia. https://doi.org/10.5962/bhl.title.50863

Bennett, F.D. 1840. Narrative of a whaling voyage round the globe, from the year 1833 to 1836 . Comprising sketches of Polynesia, California, the Indian Archipelago, etc. with an account of southern whales, the sperm whale fishery, and the natural history of the climates visited. Vol. 2, 395 pp, Richard Bentley, London. https://www.biodiversitylibrary.org/item/59619

BirdLife International 2017. IUCN Red List for birds. Downloaded from http://www.birdlife.org on 23/06/2017.

Boddaert, P. 1783. Table des planches enluminéez d'histoire naturelle de M. D'Aubenton: avec les denominations de M.M. de Buffon, Brisson, Edwards, Linnaeus et Latham, precedé d'une notice des principaux ouvrages zoologiques enluminés. Utrecht: 1-58. https://doi.org/ 10.5962/bhl.title.39835

Bonaparte, C.L. 1856. Espèces nouvelles d'oiseaux d'Asie et d'Amérique, et tableaux parallèliques des pélagiens ou Gaviae. Comptes Rendus Hebdomadaires des Séances de I'Académie des Sciences, Paris, 42:764-776. https://www.biodiversitylibrary.org/item/16554

Bonaparte, C.L. 1857. Conspectus Generum Avium. Volume 2. Lugduni Batavorum \& E.J. Brill, Leiden, Netherlands, 232 pp. https://www.biodiversitylibrary.org/item/141377

Bonvallot, J. and Barsczus, H.G. (collab.) 1993. La géologie structurale : planche 25. In Dupon, J.-F. (ed.), Bonvallot, J. (ed.), Vigneron, E. (ed.), Gay, J.C. (collab.), Morhange, C. (collab.), Ollier, C. (collab.), Peugniez, G. (collab.), Reitel, B. (collab.), Yon-Cassat, F. (collab.), Danard, M. (coord.), and Laidet, D. (réd.). Atlas de la Polynésie Française. ORSTOM, Paris. http:// www.documentation.ird.fr/hor/fdi:38860

Brandt, J.F. 1840. Beitriige zur Kenntniss der Naturgeschichte der V6gel mit besonderer Beziehung auf Skeletbau und vergleichende Zoologie. [Read 17 March 1837]. Mémoires de l'Académie Imp. Sci. St. Pétersbourg, Ser. 6. Sci. Math., Phys. Nat. 5(2) Sci. Nat., 3:91-237, 18 plates. https://doi.org/10.5962/bhl.title.49179

Brisson, M.J. 1760. Ornithologie, ou, Méthode contenant la division des oiseaux en ordres, sections, genres, especes \& leurs variétés : a laquelle on a joint une description exacte de chaque espece, avec les citations des auteurs qui en ont traité, les noms quils leur ont donnés, ceux que leur ont donnés les différentes nations, \& les noms vulgaires. Vol 1. Ad Ripam Augustinorum, apud Cl. Joannem-Baptistam Bauche, bibliopolam, ad Insigne S. Genovesae, \& S. Joannis in Deserto, Parisiis. https://www.biodiversitylibrary.org/ bibliography/51902

Brooke, M. de L. 1995a. The breeding biology of the gadfly petrels Pterodroma spp. of the Pitcairn Islands: characteristics, population sizes and controls. Biological Journal of the Linnean Society, 56:213-231. https://doi.org/10.1111/j.1095-8312.1995.tb01086.x 
Brooke, M. de L. 1995b. The modern avifauna of the Pitcairn Islands. Biological Journal of the Linnean Society, 56:199-212. https://doi.org/10.1111/j.1095-8312.1995.tb01085.x

Burley, D., Weisler, M.I., and Zhao, J-x. 2012. High precision U/Th dating of first Polynesian settlement. PLoS ONE, 7(11): e48769. https://doi.org/10.1371/journal.pone.0048769

Christidis, L. and Boles, W.E. 2008. Systematics and taxonomy of Australian birds. Collingwood, Victoria, Australia: CSIRO Publishing.

Cibois A, Thibault, J-C. Bonillo, C., Filardi, C.E., and Pasquet, E. 2017. Phylogeny and biogeography of the imperial pigeons (Aves: Columbidae) in the Pacific Ocean. Molecular Phylogenetics and Evolution, 110:19-26. https://doi.org/10.1016/j.ympev.2017.02.016

Conte, E. and Anderson, A.J. 2003. Radiocarbon ages for two sites on Ua Huka, Marquesas. Asian Perspectives, 42:155-160. https://doi.org/10.1353/asi.2003.0018

Conte, E. and Kirch P.V. (eds.) 2004. Archaeological investigations in the Mangareva Islands (Gambier Archipelago), French Polynesia. Contribution of the Archaeological Research Facility, No. 62, University of California, Berkley. https://escholarship.org/uc/item/8n28k36r

Conte, E. and Kirch, P.V. 2008. One thousand years of human environmental transformation in the Gambier Islands (French Polynesia), pp 253-264. In Clark G., Leach, F., and O'Connor, S (eds.), Terra Australis 29, Islands of Inquiry, Colonisation, seafaring and the archaeology of maritime landscapes. http://press.anu.edu.au?p=26551

Conte, E., Kirch, P.V., Weisler, M.I., and Anderson, A.J. 2004. Archaeological field investigations, pp. 33-93. In Conte, E. and Kirch P.V. (eds.), Archaeological Investigations in the Mangareva Islands (Gambier Archipelago), French Polynesia. Contribution of the Archaeological Research Facility, No. 62, University of California, Berkley. https://escholarship.org/uc/item/ $8 \mathrm{n} 28 \mathrm{k} 36 \mathrm{r}$

Cooper, J. and Tennyson, A.J.D. 2008. Wrecks and residents: the fossil gadfly petrels (Pterodroma spp.) of the Chatham Islands, New Zealand. Oryctos, 7:223-244.

Daudin, F.M. 1802. Tableaux des sous-classes, divisions, sous-divisions, orders et genres des Oiseaux, par Le C. Lacépède; avec l'indication de toutes les espèces décrites par Buffon, et leur distribution dans chacun des genres, pp. 198-346, In Buffon, G.L.L. 1799-1802. Histoire naturelle, Dédiée au citoyen Lacépède, member de l'Institut National. Quadrupedes, vol. 14, F. Dufart, Paris. https://www.biodiversitylibrary.org/item/131624

Degland, C.D. and Gerbe, Z. 1867. Ornithologie Européenne ou catalogue descriptive, analytique et raisonné des oiseaux observés en Europe, $2^{\text {nd }}$ Ed. Vol. 2, 637 pp, J.B. Baillieré et Fils, Paris. https://www.biodiversitylibrary.org/item/32502

del Hoyo, J., Elliott, A., Sargatal, J., Christie, D.A., and de Juana, E. (eds.) 2017. Handbook of the Birds of the World Alive. Lynx Edicions, Barcelona. [retrieved from http://www.hbw.com/ on 23 June 2017].

Dickinson, E.C. and Remsen, J.V. 2013. The Howard and Moore complete checklist of the birds of the world. Aves Press, Eastbourne, UK.

Forster, T. 1817. A synoptical catalogue of British birds: Intended to identify the species mentioned by different names in several catalogues already extant. Forming a book of reference to observations on British ornithology. Nichols, Son and Bentley, London. https:// www.biodiversitylibrary.org/item/47775

Fuller, E. 1987. Extinct Birds. Viking/Rainbird, London.

Fürbringer, M. 1888. Untersuchungen zur Morphologie und systematik der Vögel. Zugleich ein Beitrag zur Anatomie de Stütz- und Bewegungsorgune. 2 vol., 1751 pp., 30 pl. T. J. Van Holkema, Amsterdam. https://www.biodiversitylibrary.org/item/111287

Gangloff, B., Shirihai, H., Watling, D., Cruaud, C., Couloux, A., Tillier, A., Pasquet, E., and Bretagnolle, V. 2012. The complete phylogeny of Pseudobulweria, the most endangered seabird genus: systematics, species status and conservation implications. Conservation Genetics, 13:39-52. https://doi.org/10.1007/s10592-011-0261-6

Gmelin, J.F. 1789. Systema naturae per regna tria naturae, secundum classes, ordines, genera, species, cum characteribus, differentiis, synonymis, locis. Regnum Animalium. $13^{\text {th }}$ edition. 1(2): 501-1032. G.E. Beer, Lipsiae (Leipzig). https://www.biodiversitylibrary.org/item/219009

Gould, J. 1844. On the Family Procellaridae [sic], with descriptions of ten new species. Annals and Magazine of Natural History, 13(82):360-368. https://doi.org/10.1080/ 03745484409442618

Gray, G.R. 1845. Order VIII Anseres, Family II. Pelecanidae, pp 666-669, In The genera of birds: comprising their generic characters, a notice of the habits of each genus, and an extensive 
list of species referred to their several genera. Vol. 3, Longman, Brown, Green, and Longmans, London. https://www.biodiversitylibrary.org/item/219683

Green, R.C. and Weisler, M.I. 2000. Mangarevan Archaeology: Interpretations using new data and 40 year old excavations to establish a sequence from 1200 to 1900 AD. Department of Anthropology \& Archaeology, University of Otago. http://hdl.handle.net/10523/5946

Green, R.C. and Weisler, M.I. 2002. The Mangarevan sequence and dating of the geographic expansion into Southeast Polynesia. Asian Perspectives, 41:213-241. https://doi.org/ 10.1353/asi.2003.0006

Green, R.C. and Weisler, M.I. 2004. Prehistoric introduction and extinction of animals in Mangareva, Southeast Polynesia. Archaeology in Oceania, 39:34-41. https://doi.org/ 10.1002/j.1834-4453.2004.tb00555.x

Greenway, J.C., 1958. Extinct and vanishing birds of the World. American Committee for International Wild Life Protection, New York.

Hekinian, R., Cheminee, J.L., Dubois, J., Stoffers, P., Scott, S., Guivel, C., Garbe-Schönberg, D., Devey, C., Bourdon, B., Lackschewtig, K., McMurtry, G., and Le Drezen, E. 2003. The Pitcairn hotspot in the South Pacific: distribution and composition of submarine volcanic sequences. Journal of volcanology and geothermal research, 121(3):219-245. https://doi.org/ 10.1016/s0377-0273(02)00427-4

Hodgson, B.H. 1836. Notices of the ornithology of Nepal. III. New genera of the Columbidae. Asiatic Researches, 19:159-164. https://www.biodiversitylibrary.org/item/137987

Horsfield, T. 1821. Systematic arrangement and description of birds from the Island of Java. Transactions of the Linnean Society of London, 13:133-200. https://doi.org/10.1111/j.10958339.1821.tb00061.x

Hume, J.P. and Walters, M. 2012. Extinct Birds. T. \& A.D. Poyser, London.

Huxley, T.H. 1867. On the classification of birds: and on the taxonomic value of the modifications of certain of the cranial bones observable in that class. Proceedings of the Zoological Society of London 1867, 415-471. https://www.biodiversitylibrary.org/item/93424

Illiger, J.K.W. 1811. Prodromus systematis Mammalium et Avium additis terminis zoographicis utriusque classis, eorumque versonie germanica. C. Salfeld, Berlin, xviii + 301 pp. https:// www.biodiversitylibrary.org/item/92917

Imber, M.J., Merton, D.V., West, J.A., and Tennyson, A.J.D. 1991. Juan Fernandez Petrels prospecting at the Chatham Islands. Notornis, 38:60-62. https://www.notornis.osnz.org.nz/ juan-fernandez-petrels-prospecting-chatham-islands

Kirch, P.V. 2007. Three islands and an archipelago: Reciprocal interactions between humans and island ecosystems in Polynesia. Earth and Environmental Science Transactions of the Royal Society of Edinburgh, 98:1-15. https://doi.org/10.1017/s1755691007000011

Kirch, P.V. 2017. On the Road of the Winds: An Archaeological History of the Pacific Islands Before European Contact. Revised and enlarged edition. University of California Press, Berkeley.

Kirch, P.V. and Conte, E. 2009. Combler une lacune dans la préhistoire de la Polynésie orientale : nouvelles données sur l'archipel des Gambier (Mangareva). Le Journal de la Société des Océanistes, 128:91-116. https://doi.org/10.4000/jso.5873

Kirch, P.V., Conte, E., Sharp, W., and Nickelsen, C. 2010. The Onemea Site (Taravai Island, Mangareva) and the human colonization of Southeastern Polynesia. Archaeology in Oceania, 45:66-79. https://doi.org/10.1002/j.1834-4453.2010.tb00081.x

Kirch, P.V., Molle, G., Nickelsen, C., Mills, P., Dotte-Sarout, E., Swift, J., Wolfe, A., and Horrocks, M. 2015. Human ecodynamics in the Mangareva Islands: a stratified sequence from NenegaIti Rock Shelter (site AGA-3, Agakauitai Island). Archaeology in Oceania, 50:23-42. https:// doi.org/10.1002/arco.5050

Lacépède, B.G.E. 1799. Tableau des sous-classes, divisions, sous-devisions, ordres et genres des oiseaux. In: Discours d'ouverture et de clôture du cours d'histoire naturelle : donné dans le Muséum National d'Histoire naturelle, l'an VII de la République : et Tableaux méthodiques des Mammifères et des Oiseaux. Plassan, Paris.

Latham, J. 1790. Index Ornithologicus, sive systema ornithologiæ: complectens Avium divisionem in classes, ordines, genera, species, ipsarumque varietates. Vol. 1. Leigh \& Sotherby, London, xviii + 920 pp. https://www.biodiversitylibrary.org/item/226470

Leach, W.E. 1820. Eleventh room, upper floor. pp. 65-70. In Anonymous (ed.). Synopsis of the contents of the British Museum. [With an introductory statement of the rise and progress of 
the museum, and of its existing constitution, and an analytical syllabus of the library, etc.] 17th edition. London: British Museum. 166 pp.

Lesson, P.-A. 1844. Voyage aux iles Mangareva (Oceanic). Mercier et Devois, Rochefort.

Linnaeus, C. 1758. Systema Naturae per Regna Tria Naturae, secundum Classes, Ordines, Genera, Species, cum characteribus, differentiis, synonymis, locis. 10th Edition, revised, Vol 1: Regnum Animale. Salvii, L. Holmiae, Stockholm, Sweden, iv + 824 pp. https:// www.biodiversitylibrary.org/item/10277

Marchant, S. and Higgins, P.J. (co-ordinators) 1990. Handbook of Australian, New Zealand \& Antarctic Birds. Vol. 1 - Ratites to Ducks. Oxford University Press, Melbourne, Australia, $1400 \mathrm{pp}$.

Marchant, S. and Higgins, P.J. (eds.) 1993. Handbook of Australian, New Zealand \& Antarctic Birds. Vol. 2. Oxford University Press, Melbourne, Australia, $984 \mathrm{pp}$.

Mathews, G.M. 1912. The Birds of Australia. Vol. 2. Witherby, London. https:// www.biodiversitylibrary.org/item/223654

Mathews, G.M. 1936. A note on the Black Fiji Petrel. Ibis, Ser. 13, 6(2):309. https://doi.org/ 10.1111/j.1474-919x.1936.tb03375.x

Mayr, G. 2016. Variations in the hypotarsus morphology of birds and their evolutionary significance. Acta Zoologica, 97:196-210. https://doi.org/10.1111/azo.12117

Meehan, H.J., McConkey, K.R., and Drake, D.R. 2002. Potential disruptions to seed dispersal mutualisms in Tonga, Western Polynesia. Journal of Biogeography, 29:695-712. https:// doi.org/10.1046/j.1365-2699.2002.00718.x

Murphy, R.C. and Pennoyer, J.M. 1952. Larger petrels of the genus Pterodroma. American Museum Novitates, 1580, 43 pp. http://hdl.handle.net/2246/4049

Olson, S.L. and Rasmussen, P.C. 2001. Miocene and Pliocene birds from the Lee Creek Mine, North Carolina. Pp. 233-365. Ray, C.E and Bohaska, D.J. (eds.), Geology and paleontology of the Lee Creek Mine, North Carolina, III. Smithsonian Contributions to Paleontology 90. https://doi.org/10.5479/si.00810266.90.1

Pratt, H.D., Bruner, P.L., and Berrett, D.G. 1987. A Field Guide the birds of Hawaii and the Tropical Pacific. Princeton University Press, Princeton.

Priddel, D., Carlile, N., Moce, K., and Watling, D. 2008. A review of records and recovery actions for the 'Critically Endangered' Fiji Petrel Pseudobulweria macgillivrayi. Bird Conservation International, 18:381-393. https://doi.org/10.1017/s0959270908007648

Pyle, P., Welch, A.J., and Fleischer, R.C. 2011. A new species of shearwater (Puffinus) recorded from Midway Atoll, Northwestern Hawaiian Islands. The Condor, 113:518-527. https://doi.org/ 10.1525/cond.2011.100117

Rafinesque, C.S. 1815. Analyse de la nature, ou Tableau de l'univers et des corps organisés. published by the author, Palermo, Italy. 224 pp. https://www.biodiversitylibrary.org/item/ 188066

Rayner, M.J., Carlile, N., Priddel, D., Bretagnolle, V., Miller, M.G.R., Phillips, R.A., Ranjard, L.S., Bury, J., and Torres, L.G. 2016. Niche partitioning by three Pterodroma petrel species during non-breeding in the equatorial Pacific Ocean. Marine Ecology Progress Series, 549:217-229. https://doi.org/10.3354/meps 11707

Reichenbach, H.G.L. 1853. Pp iv, Die Vogel. The Birds - Aves - Les Oiseaux, In Reichenbach, H.G.L. 1849-53. Avium systema naturale: das natürliche System der Vögel mit hundert Tafeln grosstentheils Original-Abbildungen der bis jetzt entdecken fast zwölfhundert typischen Formen. Vorläufer einer Iconographie der Arten der Vögel aller Welttheile, welche, nachdem bereits fast dreitausend Abbildungen erscheinen sind, ununterbrochen fortgesetzt wird. Expedition der vollstandigsten Naturgeschichte 1850, Dresden \& Leipzig. 100 pp., 100 pls. https://www.biodiversitylibrary.org/item/103886 [in part; publication date incorrect].

Salvin, O. 1888. Critical notes on the Procellariidae. Ibis, 6(Ser. 5):351-360. https://doi.org/ 10.1111/j.1474-919x.1888.tb08491.x

Salvin, O. 1896. Catalogue of the Gaviae and Tubinares in the collection of the British Museum. Catalogue of the birds in the British Museum, vol. 25, 475 pp. Taylor and Francis, London. https://www.biodiversitylibrary.org/item/34471

Sharpe, R.B. 1891. A Review of Recent Attempts to Classify Birds; an address delivered before the Second International Ornithological Congress. Hungarian Committee of Second International Ornithological Congress, Budapest, 90 pp. https://www.biodiversitylibrary.org/ item/47733 
Shirihai, H., Pym, T., Kretzschmar, J., Moce, K., Taukei, A., and Watling, D. 2009. First observations of Fiji Petrel Pseudobulweria macgillivrayi at sea off Gau Island, Fiji, in May 2009. Bulletin of the British Ornithological Club, 129(3):129-148. http://boc-online.org/ bulletins/downloads/Pseudobulweria\%20macgillivrayi\%20Shirihai\%20et\%20al.pdf

Sparrman, A. 1786. Museum Carlsonianum, in quo novas et selectas aves, coloribus ad vivum brevique descriptione illustratas, suasu et sumtibus generosissimi possessoris. Fasc. 1: no XI, pl. 11, Ex Typographia Regia, Holmiae. https://doi.org/10.5962/bhl.title.62901

Steadman, D.W. 1989a. Extinction of birds in eastern Polynesia: A review of the record, and comparisons with other Pacific Island groups. Journal of Archaeological Science, 16:177205. https://doi.org/10.1016/0305-4403(89)90065-4

Steadman, D.W. 1989b. New species and records of birds (Aves: Megapodiidae, Columbidae) from an archaeological site on Lifuka, Tonga. Proceedings of the Biological Society of Washington, 102:537-552. https://www.biodiversitylibrary.org/item/107493

Steadman, D.W. 1992. New species of Gallicolumba and Macropygia (Aves: Columbidae). Los Angeles County Museum of Natural History, Science Series, 36:329-348.

Steadman, D.W. 1993. Biogeography of Tongan birds before and after human impact. Proceedings of the National Academy of Science U.S.A., 90:818-822. https://doi.org/ 10.1073/pnas.90.3.818

Steadman, D.W. 1995. Prehistoric extinctions of Pacific island birds: Biodiversity meets zooarchaeology. Science, 267:1123-1131. https://doi.org/10.1126/science.267.5201.1123

Steadman, D.W. 1997. The historic biogeography and community ecology of Polynesian pigeons and doves. Journal of Biogeography, 24:737-753. https://doi.org/10.1046/j.13652699.1997.00157.x

Steadman, D.W. 2006. Extinction and Biogeography of Tropical Pacific Birds. The University of Chicago Press, Chicago \& London.

Steadman, D.W. and Justice, L. 1998. Prehistoric Exploitation of Birds on Mangareva, Gambier Islands, French Polynesia. Man and culture in Oceania, 14:81-98.

Streets, T.H. 1877. Contributions to the Natural History of the Hawaiian and Fanning Islands and Lower California made in connection with the United States North Pacific Surveying Expedition, 1873-75. Bulletin of the United States National Museum, 1(7):1-172. https:// www.biodiversitylibrary.org/item/100798

Swainson, W. 1825. On the characters and natural affinities of several new birds from Australasia; including some observations on the Columbidae. Zoological Journal London, 1:463-484. https://www.biodiversitylibrary.org/item/48988

Swift, J., Miller, M.J., and Kirch, P.V. 2016. Stable isotope analysis of Pacific rat (Rattus exulans) from archaeological sites in Mangareva (French Polynesia): Implications for nutrient flows in island socio-ecosystems. Environmental Archaeology, 22:283-297. https://doi.org/10.1080/ 14614103.2016.1216933

Temminck, C.J. 1820. Manuel d'ornithologie, ou, Tableau systématique des oiseaux qui se trouvent en Europe; précédé d'une analyse du système général d'ornithologie, et suivi d'une table alphabétique des espèces, 2nd edn. Gabriel Dutour, Paris, France. https:// www.biodiversitylibrary.org/item/127471

Tennyson, A.J.D. and Anderson, A. 2012. Bird, reptile and mammal remains from archaeological sites on Rapa Island. pp. 105-114. In Anderson, A. and Kennett, D.J. (eds.), Taking the High Ground. The archaeology of Rapa, a fortified island in remote east Polynesia. Terra Australis 37. Australian National University Press, Canberra, Australia. https://doi.org/10.22459/ ta37.11.2012.06

Tennyson, A.J.D., Cooper, J., and Shepherd, L. 2015. A new species of extinct Pterodroma petrel (Procellariiformes: Procellariidae) from the Chatham Islands, New Zealand. Bulletin of the British Ornithologists' Club, 135(3):267-277.

Thibault, J.-C. and Cibois, A. 2012. From early Polynesian settlements to the present: bird extinctions in the Gambier Islands. Pacific Science, 66(3):271-281. https://doi.org/10.2984/ 66.3 .2

Thibault, J.-C. and Cibois, A. 2017. Birds of Eastern Polynesia. A biogeographic atlas. Lynx Edicions, Barcelona.

Thibault, J.-C. and Bretagnolle, V. 1999. Breeding seabirds of Gambier Islands, Eastern Polynesia: Numbers and changes during the 20th Century. Emu, 99:100-107. https://doi.org/ $10.1071 /$ mu99013 
Villard, P., Dano, S., and Bretagnolle, V. 2006. Morphometrics and the breeding biology of the Tahiti Petrel Pseudobulweria rostrata. Ibis, 148:285-291. https://doi.org/10.1111/j.1474919X.2006.00528.x

Wagler, J.G. 1832. Isis von Oken, Heft 11: col. 1223. https://www.biodiversitylibrary.org/item/ 85170

Walker, C.A., Wragg, G.M., and Harrison, C.J.O. 1990. A new shearwater from the Pleistocene of the Canary Islands and its bearing on the evolution of certain Puffinus shearwaters. Historical Biology, 3:203-224. https://doi.org/10.1080/08912969009386522

Walther, M. and Hume, J.P. 2016. Extinct birds of Hawai'i. Mutual Publishing, Hawai'i.

Warham, J. 1990. The petrels: their ecology and breeding systems. i-viii, 440 pp; Academic Press, London.

Watling, D. and Lewanavanua, R.F. 1985. A note to record the continuing survival of the Fiji (MacGillivray's) Petrel Pseudobulweria macgillivrayi. Ibis, 127:230-233. https://doi.org/ 10.1111/j.1474-919x.1985.tb05056.x

Waugh, S., Champeau, J., Cranwell, S., and Faulquier, L. 2013. Seabirds of the Gambier Archipelago, French Polynesia, in 2010. Marine Ornithology, 41:7-12. http:// www.marineornithology.org/content/get.cgi?rn=1001

Weisler, M.I. 1996. An archaeological survey of Mangareva: Implications for regional settlement models and interaction studies. Man and Culture in Oceania, 12:61-85.

Wilmshurst, J.M., Anderson, A.J., Higham, T.F.G., and Worthy, T.H. 2008. Dating the late prehistoric dispersal of Polynesians to New Zealand using the commensal Pacific rat. Proceedings of the National Academy of Sciences, U. S. A., 105:7676-7680. https://doi.org/ 10.1073/pnas.0801507105

Worthy, T.H. 2001. A giant flightless pigeon gen. et sp. nov. and a new species of Ducula (Aves: Columbidae), from Quaternary deposits in Fiji. Journal of the Royal Society of New Zealand, 31:763-794. https://doi.org/10.1080/03014223.2001.9517673

Worthy, T.H., Hawkins, S., Bedford, S. and Spriggs, M. 2015. Avifauna from the Teouma Lapita Site, Efate Island, Vanuatu, including a new genus and species of megapode. Pacific Science, 69(2):205-254. https://doi.org/10.2984/69.2.6

Worthy, T.H. and Tennyson, A.J.D. 2004. Avifaunal assemblages from the Nenega-lti and Onemea sites. pp. 122-127. Chapter 6. In Conte, E.and Kirch, P.V. (eds.) Archaeological investigations in the Mangareva Islands (Gambier Archipelago), French Polynesia. Archaeological Research Facility, University of California, Berkeley, California. https:// escholarship.org/uc/item/8n28k36r

Worthy, T.H. and Wragg, G.M. 2003. A new species of Gallicolumba: Columbidae from Henderson Island, Pitcairn Group. Journal of the Royal Society of New Zealand, 33:769-793. https://doi.org/10.1080/03014223.2003.9517758

Worthy, T.H. and Wragg, G.M. 2008. A new genus and species of pigeon (Aves: Columbidae) from Henderson Island, Pitcairn Group, pp. 499-510. In Clark, G., Leach, F., and O'Connor, S. (eds.), Terra Australis 29. Islands of Inquiry: Colonisation, seafaring and the archaeology of maritime landscapes. ANU E Press, The Australian National University, Canberra. 510 pp. http://press.anu.edu.au?p=26551

Wragg, G.M. and Worthy, T.H. 2006. A new species of extinct imperial pigeon (Ducula: Columbidae) from Henderson Island, Pitcairn Group. Historical Biology, 18:127-140. https:// doi.org/10.1080/08912960600640853

Wragg, G.M. 1995. The fossil birds of Henderson Island, Pitcairn Group: natural turnover and human impact, a synopsis. Biological Journal of the Linnean Society, 56:405-414. https:// doi.org/10.1111/j.1095-8312.1995.tb01100.x 


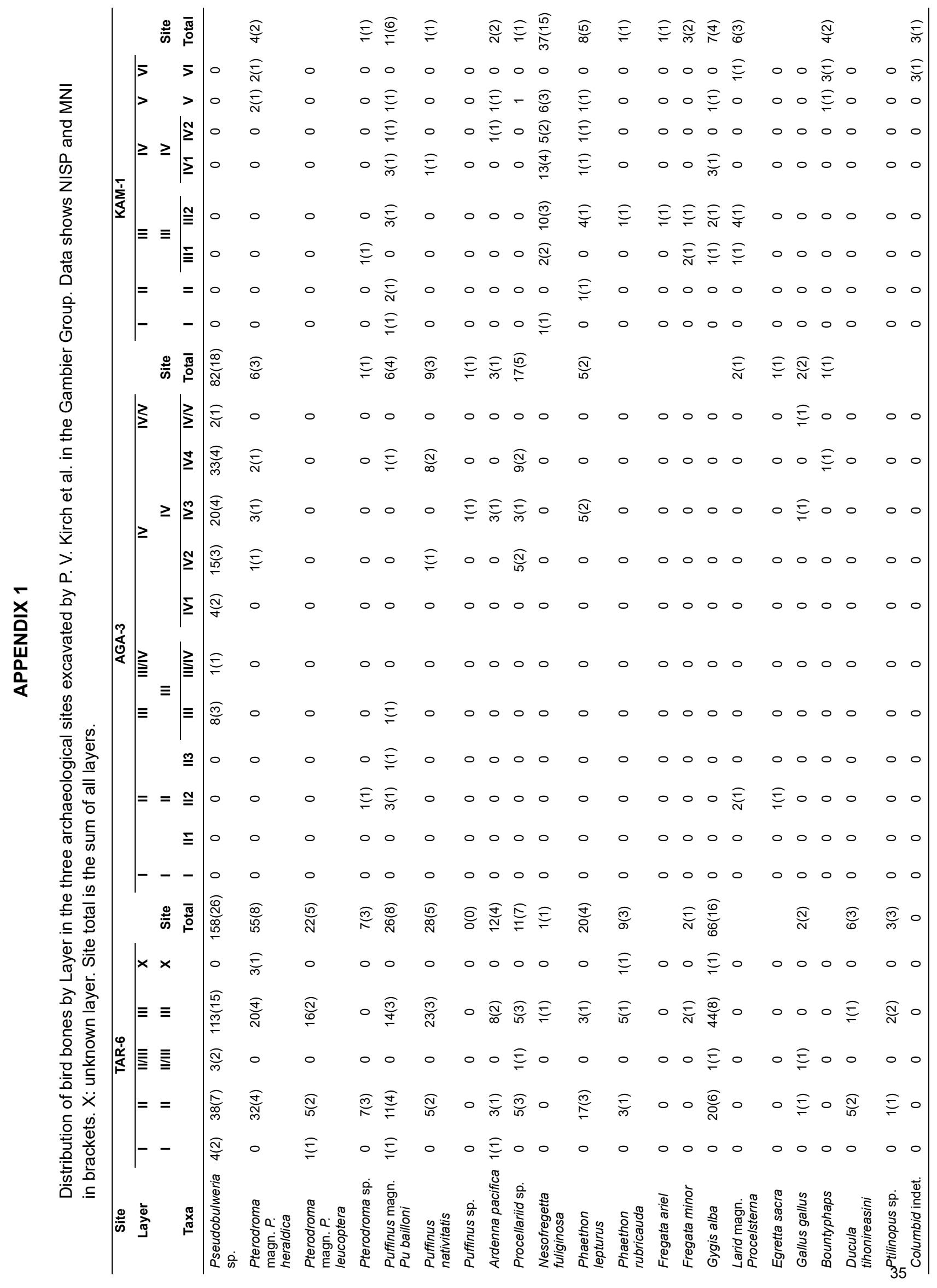

